\title{
Orographic Effects on Cold Surges and Lee-Cyclogenesis as Revealed by a Numerical Experiment Part I. Time Mean Aspects
}

\author{
By Hajime Nakamura \\ Geophysical Institute, University of Tokyo, Tokyo 113, Japan \\ and \\ Takio Murakami ${ }^{1}$ \\ Department of Meteorology, University of Hawaii, \\ Honolulu, Hawaii 96822, U.S.A. \\ (Manuscript received 13 January 1983, in revised form 8 May 1983)
}

\begin{abstract}
A 10-layer dry numerical model which includes convective adjustment, surface friction, and vertical momentum diffusion is used to identify the mechanical effects of a- mountain on transient eddies during winter. Thermal effect is simplified to the form of Newtonian cooling. Observed winter zonal mean temperature is prescribed as an equilibrium state. The mountain has a simple elliptic shape. The numerical integration was performed for 72 days, but a detailed analysis was done only for the 16-day period from day 21 to day 36 .

The 16-day mean fields show that the westerly jet tends to flow around, rather than over the mountain and splits into two branches in the lower troposphere. At $500 \mathrm{mb}$, winds are weakest over the mountain with a distinct splitting of the jet north and south of the mountain. Above $300 \mathrm{mb}$, the jet flows south of the mountain. These features agree well with those of the 1978-79 winter mean fields (Murakami, 1981a).

At $850 \mathrm{mb}$, significant temperature perturbations originate at the northwest periphery of the mountain and extend clockwise around the mountain until reaching the southern part of the mountain. These low-level disturbances, which are trapped below $700 \mathrm{mb}$ along the periphery of the mountain, are referred to as "edge" disturbances in this paper. These edge disturbances receive their eddy available potential energy via nonlinear interaction with 16day mean temperature fields. Their eddy available potential energy is not converted into eddy kinetic energy; namely, the baroclinic conversion process contributes little to the development of edge disturbances. They acquire their kinetic energy through flux convergence of geopotential energy due to the nongeostrophic components of winds.

At $500 \mathrm{mb}$, the kinetic energy of the disturbances is weakest, and baroclinic conversion is directed from eddy kinetic to the available potential energy, over the mountain. Here, the major contributing process in the generation of eddy kinetic energy is the horizontal flux convergence of eddy geopotential energy. The disturbances supply (extract) energy to (from) 16-day mean winds outside (over) the mountain.

At $200 \mathrm{mb}$, a belt of large eddy kinetic energy lies south of the mountain, where the strong upper tropospheric jet stream prevails. The barotropic conversion process feeds energy to the 16-day mean westerly flows there. Again, the major generation factor for eddy kinetic energy is the flux convergence of eddy geopotential energy, while other terms, such as, baroclinic conversion are negligible.
\end{abstract}

\section{Introduction}

The Tibetan Plateau exerts a strong effect on the atmospheric motion over Asia in winter.

1 Contribution No. 82-08, Department of Meteorology, University of Hawaii, Honolulu.
Outbursts of cold air from Siberia propagate southward along the eastern periphery of the Tibetan Plateau, reaching as far sourth as Malaysia and Indonesia, where cumulus activity is vigorous. This is a region of heavy equatorial rainfall (Chang et al., 1979). The Winter Mon- 
soon Experiment (December 1978) was a special observational program to investigate the role of cold surges in the generation and development of equatorial disturbances in this area.

There are also strong interactions between the subtropical westerlies and the Tibetan Plateau. The subtropical jet is weakest over the mountain area and strongest over Japan, about $2000 \mathrm{~km}$ downstream of the Plateau. There have been many observational and theoretical studies concerning the interaction of atmospheric flows with mountains. One may refer to an excellent review by Kasahara (1979).

Chinese meteorologists (Staff Members, Academia Sinica, 1957, 1958a and b) have made an extensive study on the effect of the Tibetan Plateau on daily and winter mean circulation. They found that during winter: (1) the low-level westerly jet splits into two branches and flow around, rather than up and over, the high mountains of the Tibetan Plateau; (2) there is a large area of weak winds in the lower atmosphere between the two jet branches to the east of the Tibetan Plateau; (3) a strong upper-level (200$300 \mathrm{mb}$ ) jet stream flows along the southern periphery of the Plateau. They also found that: (4) transient disturbances in winter split to the north and south as they approach the Tibetan Plateau; (5) the southern cell moves very slowly toward India with decreasing intensity; (6) the northern cell propagates eastward much faster than the southern counterpart; and (7) small vortices are frequently formed along the shear line downstream of the Plateau. These findings are very interesting. However, since the study was based on relatively sparse data during the 1950's a verification with more recent data was needed. In this regard, a book entitled Meteorology over the Tibetan Plateau, edited by Yeh and Gao (1979), was published by Chinese meteorologists. This summarizes a very extensive research effort based on about 10 years (1961-70) of station data.

Murakami (1981a, b, and c) investigated the 1978-79 winter circulation over and around the Tibetan Plateau, using the FGGE Level IIIa data compiled by the National Meteorological Center, Washington, D.C. The FGGE data coverage around the Tibetan Plateau was greatly improved as compared to the pre-FGGE period. His results were similar to those of the Chinese meteorologists. In addition, he found that: (1) the Ekman layer over the mountains with about
$1.5 \mathrm{~km}$ thickness weakens the westerly jet at $500 \mathrm{mb}$; (2) upper tropospheric flows between 500 and $200 \mathrm{mb}$ are characterized by weak winds above the Plateau and, thus, exhibit features that are similar to the Taylor column phenomenon; (3) the acceleration of the westerly jet at $200 \mathrm{mb}$ south and downstream of the Plateau is due to the southerly non-geostrophic flow associated with a local Hadley circulation between China, Malaysia, and Indonesia. $\mathrm{He}$ also investigated the maintenance of winter mean temperature, vorticity, and zonal wind fields in the vicinity of the Tibetan Plateau.

Murakami (1981b and c) found three dominant frequency periods in the power spectra of the meridional winds, i.e., 3.5-5.5, 6-9, and 1220 days. His results showed that short-period (3.5-5.5 days) disturbances are weak over the Tibean Plateau and they split into two parts (north and south) as they approach the western region of the Tibetan Plateau. The southern part moves slowly along the southern periphery of the Himalayas into India while decreasing in intensity. The northern one moves faster than the southern counterpart. These facts agree with the findings by the Chinese meteorologists mentioned earlier.

Of particular interest in Murakami's study is that small-scale, low-level (below $700 \mathrm{mb}$ ) disturbances develop near the northeastern periphery of the Tibetan Plateau. These disturbances then move southward along the eastern border of the Plateau and become most intense over the Red Basin before dissipating near the southeastern corner of the Plateau. When these orographically-induced anticyclonic cells in the lee of the Tibetan Plateau are strong and interact with approaching upper tropospheric troughs, the low-level cold monsoonal surges over central China become strongest and reach the equatorial South China Sea.

Lee-cyclogenesis is one of the important phenomena associated with mountains. Chung et al. (1976) showed that cyclogenesis frequently occurs in the lee of the Tibetan Plateau and they provided a detailed description of its frequency, paths, and structures. However, the exact mechanisms of lee-cyclogenesis east of the Plateau are still not known. Though there are some studies concerning the lee cyclones around the Alps (Speranza, 1975; Buzzi and Tibaldi, 1977b) and the Rockies (Carlson, 1961), it is still far from a complete understanding of lee-cyclogenesis. 
Since the Tibetan Plateau is a huge massif with the highest elevation in the world, the cyclogenesis in the lee of the Tibetan Plateau may be different from those of the Alps and the Rockies. Unfortunately, we have very little knowledge about the details of lee-cyclogenesis downstream of the Tibetan Plateau because of sparse data coverage in this area until recently.

Beginning with Fultz (1951), annulus experiments have been widely used to study orographic effects. Yeh and Chang (1974) performed an annulus simulation of the general circulation over eastern Asia. They placed an elliptic-shaped mountain in westerly flows within a rotating annulus. An electric heater was used to investigate the thermal effect of the mountain. Yeh and Chang showed that the splitting of the jet occurs without heating the mountain. This suggests that the splitting of the westerly jet in winter near the Tibetan Plateau may be explained by the mechanical effect of these high mountains. They also showed that transient vortices split when they approach the mountain. A research group, Academic Sinica (1977), was also able to simulate cyclogenesis of small-scale vortices near the southeastern periphery of the Tibetan Plateau.

Numerical simulation is another useful method to investigate the effect of mountains on atmospheric flows. Manabe and Terpstra (1974) made a numerical experiment with the GFDL general circulation model (GCM) to identify the orographic influence on the winter general circulation. They showed, for example, that when the mountains are included in the model, westerly flows in the middle latitudes became weak over the mountains. This resembles the situation in the real atmosphere. For transient disturbances, they showed that the mountains are important in causing frequent cyclogenesis downstream of the Tibetan Plateau and the Rockies. When mountains are not included in the model, there are no favorable areas of frequent cyclogenesis.

The GCM experiments mainly focused on mean fields and statistical aspects of disturbances. Therefore, it is difficult to obtain insight about the interaction between each particular disturbance and mountains. There have been a number of numerical simulations on lee-cyclogenesis in the Alps (Egger, 1972; Trevisan, 1975; and Bleck, 1977), but there has not been a numerical experiment pertaining to the lee-cyclogenesis around the Tibetan Plateau.

A number of theories have been proposed for lee-cyclogenesis. Buzzi and Tibaldi (1977a) suggested the effect of the Ekman layer friction as being important for lee-cyclogenesis. Huppert and Bryan (1976) showed that a sudden change in the incoming flow west of the mountain may cause transient disturbances downstream. However, since these theories are based on simple assumptions, such as, a barotropic atmosphere, we should re-examine these theories with a more sophisticated numerical model.

The objective of this paper is to investigate and clarify to some extent the interaction between transient disturbances and a mountain (particularly the Tibetan Plateau) in winter. More specifically, we are interested in the phenomena of cold surges and lee-cyclogenesis. Thus, we will first try to simulate the basic winter mean general circulation over and around the Tibetan Plateau, since synoptic and small-scale disturbances are strongly controlled by basic large-scale flow fields. Then, we will focus on disturbances generated in the model and examine the effect of the mountain on cold surges and lee-cyclogenesis.

Our objective is not to simulate the general circulation over the globe, but to investigate particular disturbances around the Tibetan Plateau in winter; therefore, the physics of the model is greatly simplified. Since the staff members of Academia Sinica (1958b) showed that the thermal effect is insignificant in winter over the Tibetan Plateau, we simplify the radiation process to the form of Newtonian cooling. Moisture is also not included. Moreover, the Ekman boundary layer is not included in this study, although Murakami (1981a) showed the importance of the Ekman layer over the Tibetan Plateau. The mountain also has an idealized, elliptical shape, which is a hypothetical facsimile of the Tibetan Plateau.

In Part I, we will describe the model and present the time mean state and some statistics on transient eddies. Part II will discuss some synoptic features, such as, phase speed and the structure of the disturbances over and around the mountain. The mechanisms which generate and maintain cold surges and lee-cyclones will also be discussed in Part II.

\section{Model}

\subsection{Numerical aspects}

Primitive equations in $\sigma$-coordinate (Phillips, 1957) may be written as the following: 


$$
\begin{aligned}
& \frac{\partial \pi}{\partial t}+\nabla \cdot(\pi v)+\frac{\partial}{\partial \sigma}(\pi \dot{\sigma})=0, \\
& \frac{\partial \Phi}{\partial\left(p^{c}\right)}=-c_{p} \theta, \\
& \frac{\partial \pi v}{\partial t}+\nabla \cdot(\pi v v)+\frac{\partial}{\partial \sigma}(\pi \dot{\sigma} v)+f k \times \pi v \\
& \quad=-\nabla(\pi \Phi)+\frac{\partial}{\partial \sigma}(\Phi \sigma) \nabla \pi+\pi F, \\
& \frac{\partial \pi T}{\partial t}+p^{*} \nabla \cdot(\pi v \theta)+p^{*} \frac{\partial}{\partial \sigma}(\pi \dot{\sigma} \theta) \\
& \quad=\pi \sigma \alpha \frac{\partial \pi}{\partial t}+\pi Q,
\end{aligned}
$$

where $\sigma=\left(p-p_{t}\right) / \pi$ and $\pi=p_{s}-p_{t} ; p_{s}$ is surface pressure, $p_{t}$ is pressure at the top of the model, and $\dot{\sigma}$ is vertical $\sigma$-velocity $(d \sigma / d t) . \quad F$ and $Q$ are friction and diabatic heating, respectively. The other variables are listed in Appendix I.

We used a finite-differencing method based on an old version of the UCLA general circulation model (Arakawa, 1972), which was designed by a careful examination of conservative laws. The possibility of large truncation errors over a mountain exists in a $\sigma$-coordinate finite differencing scheme because $\sigma$-surfaces incline over mountain slopes, and the pressure gradient forces are evaluated as small differences between the two large terms with opposite signs. Many new schemes have been proposed to reduce the errors in the hydrostatic equation and pressure gradient force (Corby et al., 1972; Phillips, 1974; Simmons and Burridge, 1981; and Arakawa and Suarez, 1983). Nakamura (1978a, b) surveyed the numerical schemes proposed so far and found some of them have reasonably small errors when the mountain slopes are not as sharply declined as at the southern border of the Himalayas. In this study, the form of the finitedifference of the hydrostatic equation, thermodynamic equation, and pressure gradient force was determined so as to minimize the errors along the mountain slope. Our numerical model conserves energy, angular momentum, potential temperature, and potential temperature square. It satisfies the requirement for the pressure gradient force at the surface with reference to surface torque.

The domain of integration is a hemisphere. The boundary at the equator is assumed to be a slip and rigid wall, that is, $v=0$ and $u, \Phi, T$ are symmetric about the equator. Top of the model is $0 \mathrm{mb}$. Horizontal grid size is 2.5 degrees. A staggered grid is used (Grid B in Arakawa, 1972). The model has 10 layers in the vertical, among which 7 layers with equal thickness of 0.115 are in the troposphere and 3 unequally spaced layers in the stratosphere. These resolutions may not be adequate to resolve small-scale, low-level disturbances around a mountain. We will discuss this problem in Part II.

TASU-Matsuno scheme and leap-frog scheme are used alternatively in a cycle of 12 time steps with a time increment of 5 minutes. Fourier filtering is used to avoid computational instability near the pole. Nonlinear horizontal viscosity is used in the model.

\subsection{Physics}

Physics included are convective adjustment, vertical momentum mixing, and surface drag. The latter two may be written as the following:

$$
\boldsymbol{F}=-\frac{g}{\pi} \frac{\partial \tau}{\partial \sigma}
$$

where

$$
\tau=-g K_{m} \rho^{2} \frac{1}{\pi} \frac{\partial v}{\partial \sigma} .
$$

and

$$
\boldsymbol{\tau}_{s}=\rho c_{D}\left|\boldsymbol{v}_{s}\right| \boldsymbol{v}_{s} ; \boldsymbol{v}_{s}=\boldsymbol{v} \text { (at lowest } \sigma \text {-layer). }
$$

We used a constant value of $1 \mathrm{~m}^{2} / \mathrm{s}$ for the vertical momentum mixing coefficient $K_{m}$, and 0.001 for surface drag coefficient $c_{D}$. No further parameterization of the planetary boundary layer effect is included in the present model.

For convective adjustment a diffusion type scheme is adopted, i.e.,

$$
\begin{aligned}
Q_{c} & =\frac{1}{\rho} \frac{\partial}{\partial z}\left[K_{t}\left(\frac{\partial T}{\partial z}-\Gamma\right)\right], & \text { if } \frac{\partial T}{\partial z}<\Gamma, \\
& =0, & \text { if } \frac{\partial T}{\partial z} \geqq \Gamma,
\end{aligned}
$$

where $K_{t}$ is the vertical thermal mixing coefficient and $\Gamma$ is the critical lapse rate. In the model, $K_{t}$ is $120 \mathrm{~m}^{2} / \mathrm{s}$ so as to parameterize a strong convective mixing. $\Gamma\left({ }^{\circ} \mathrm{C} / \mathrm{km}\right)$ is a function of latitude as follows:

$$
\Gamma(\phi)=-7.4-0.4 \cos 3 \phi,
$$

where $\phi$ is latitude.

\subsection{Mountain}

We specified a simple shape for the mountain with height given as follows: 


$$
\begin{aligned}
h & =h_{0}\left(e^{-x^{2}}-h_{c}\right), & & \text { if } x^{2} \leq 5, \\
& =0, & & \text { if } x^{2}>5,
\end{aligned}
$$

where

$$
\begin{aligned}
& h_{0}=5 \mathrm{~km}, \quad h_{c}=e^{-5}, \\
& x^{2}=\left(\frac{\lambda-\lambda_{0}}{10}\right)^{2}+\left(\frac{\phi-\phi_{0}}{7.5}\right)^{2}
\end{aligned}
$$

$\lambda$ is longitude and $\phi$ is latitude; $\lambda_{0}=90^{\circ} \mathrm{E}$ and $\phi_{0}=36.25^{\circ} \mathrm{N}$. The mountain is elliptic on the horizontal plane and Gaussian shaped in the vertical cross-section. Size is about 40 degrees in longitude and 30 degrees in latitude, with the center at nearly the same latitude as that of the Tibetan Plateau. This mountain as compared with the Tibetan Plateau is considerably smoother. However, this will minimize truncation errors associated with $\sigma$-coordinate system mentioned earlier.

\subsection{Forcing and initial field}

We used Newtonian cooling to simplify thermal forcing. The model's equilibrium temperature is assumed to depend only on latitude. Newtonian cooilng may be written as:

$$
Q_{N}=-k\left(T-T_{e}\right) \text {, }
$$

where $k$ is the relaxation time constant and $T_{e}$ is equilibrium temperature.

The coefficient $k$ is assumed to be $1 /(20$ days $)$ except at the top layer where $k=1 /(5$ days $)$. This is because the top layer may work as a sponge layer to absorb upward propagating planetary waves and, thus, inhibits unrealistic reflection of the waves due to the top boundary condition of $\omega=0$ at $p=0 \mathrm{mb}$ (Nakamura, 1976; Kirkwood and Derome, 1977).

$T_{e}$ is a function of latitude and $\sigma$, and is calculated from the thermal wind equation using observed January mean geostrophic wind data by Crutcher (1961) for the troposphere and from the Berlin maps for the stratosphere. The detailed process to obtain $T_{e}$ in the model is shown in Appendix II. Fig. 1 shows latitude-height cross-sections of equilibrium temperature and initial zonal wind. They are representative of winter mean fields. It must be pointed out that the lapse rate of $T_{e}$ is smaller than the critical lapse rate of convective adjustment so that the equilibrium state is stable for convective adjustment. Moreover, Rayleigh's condition of barotropic instability is not met for the meridional profile of $u_{e}$ in the initial state.

\subsection{Time integration}

Time integration started with the zonally sym-

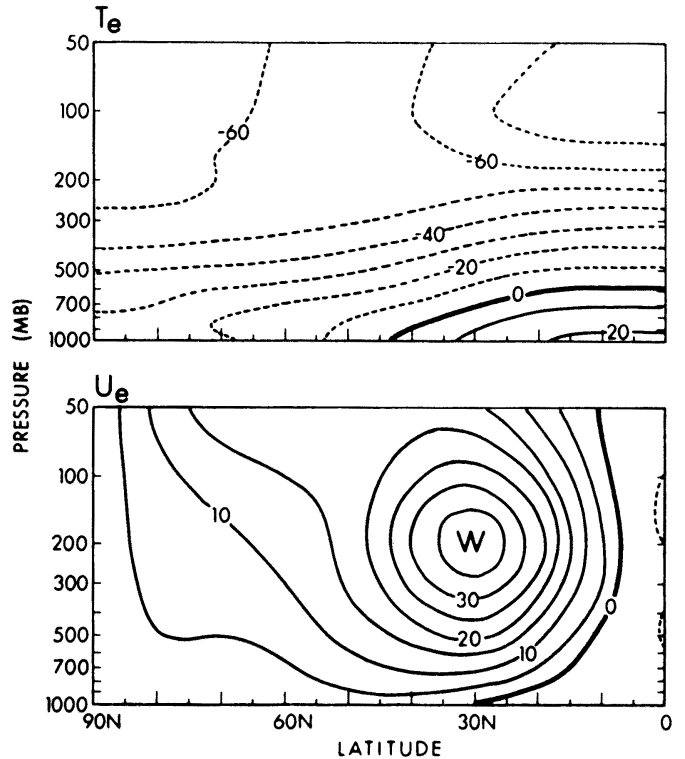

Fig. 1 Latitude-height section of temperature $T_{e}$ (top; $10^{\circ} \mathrm{C}$ interval) and zonal mean winds $U_{e}$ (bottom; $5 \mathrm{~ms}^{-1}$ interval) in initial state. Refer to eqs. 9, A1, and A2 for further information on the determination of $T_{e}$ and $U_{e}$.

metric equilibrium state and with no mountain. We introduced the mountain gradually from day 3 to day 10 so as to reduce noise to a level as low as possible. Large-scale disturbances were generated by the introduction of the mountain. At first, these disturbances were mostly barotropic in character, and propagated downstream, eventually they became barcolinic-type waves. By day 20 disturbances traveled around the earth reaching the upstream area of the mountain. They were fully developed and passed through the mountain area after day 20.

Integration continued until day 72. However for this study, we will examine the period between day 21 and 36 in detail, during which interesting synoptic events occurred around the mountain. For convenience, hereafter, the numbering of days will be changed to: day 0 to day 15 rather than day 21 to 36 . Computed results were stored at every 3 hour interval so that short term phenomena could be analyzed. The area of analysis is from $55^{\circ} \mathrm{E}$ to $135^{\circ} \mathrm{E}$ and $15^{\circ} \mathrm{N}$ to $60^{\circ} \mathrm{N}$ with the mountain being approximately at its center.

Data at $\sigma$-levels in the model are interpolated in the vertical to 19 pressure levels from $950 \mathrm{mb}$ to $50 \mathrm{mb}$ with a $50 \mathrm{mb}$ interval. Interpolation 
method is splines under tension (NCAR, 1976). Appendix III describes details of conversion from $\sigma$ to $p$.

Hereafter, ( - ) denotes 16-day time mean between day 0 and day 15 and ()$^{\prime}$ indicates deviation from time mean computed at 3-hour intervals.

\section{16-day mean wind and vorticity fields}

16-day time mean wind fields at 850,700 , 500 , and $200 \mathrm{mb}$ are shown in Figs. 2 and 3, respectively. At $850 \mathrm{mb}$ (Fig. 2, bottom), 16-day mean winds tend to flow around, rather than over the mountain. The westerly flow upstream of the mountain splits into two streams when it approaches the mountain. The northern branch flows northeastward parallel to the mountain boundary (about $1.5 \mathrm{~km}$ height contour), then turns eastward at the northern periphery of the mountain. Wind velocity of the northern branch reaches a maximum $(10 \mathrm{~m} / \mathrm{s})$ along the northwestern periphery of the mountain. The south-



Fig. 2 16-day mean wind fields with isotaches (full lines) at intervals of $2 \mathrm{~ms}^{-1}$. Top: $700 \mathrm{mb}$ wind vectors with full (half) bar corresponding to $5(2.5) \mathrm{ms}^{-1}$. Hatching (dashed hatching) indicates regions of greater (less) than $10(4) \mathrm{ms}^{-1}$. Heavy full lines represent $3 \mathrm{~km}$ height contour of the mountain. Bottom: $850 \mathrm{mb}$ wind vectors; half bar $\sim 1.5 \mathrm{~ms}^{-1}$, and full bar $\sim 3 \mathrm{~ms}^{-1}$. Hatching (dashed hatching) indicates regions of greater (less) than $8(2)$ $\mathrm{ms}^{-1}$. Heavy full lines represent $1.5 \mathrm{~km}$ height contour of the mountain. 
ern branch is considerably weaker $(5 \mathrm{~m} / \mathrm{s})$ than the northern branch, having its weakest point at the southwestern periphery and reintensifying in the southeastern area. The two branches tend to converge into one major stream in the lee of the mountain around $125^{\circ} \mathrm{E}$. There is a zone of extremely weak winds $(<2 \mathrm{~m} / \mathrm{s})$, which extends approximately $1000 \mathrm{~km}$ downstream. The flow at $700 \mathrm{mb}$ (Fig. 2, top) also has similar features to those at $850 \mathrm{mb}$, although the westerlies are stronger.

Fig. 4 (bottom) shows observed $700 \mathrm{mb}$ winter mean flow fields around the Tibetan Plateau obtained by Murakami (1981a). Although the numerical model assumes a simplified situation, simulated time mean flows at $850 \mathrm{mb}$ and/or $700 \mathrm{mb}$ (Fig. 2) agree quite well with the observed flow at $700 \mathrm{mb}$ around the Tibetan Plateau.

In Fig. 3 (bottom), an interesting feature of the $500 \mathrm{mb}$ winds is that they are weak $\left(<15 \mathrm{~ms}^{-1}\right)$ over the mountain. This agrees well with Murakami's (1981a) observational study (Fig. 4, middle). In the model, however, deceleration of the wind over the mountain is not as pronounced as that over the Tibetan Plateau. Murakami (1981a) suggested that the Ekman boundary layer effect may be important in the weakening of the $500 \mathrm{mb}$ flow over the Plateau. Since our model does not parameterize the Ekman boundary layer

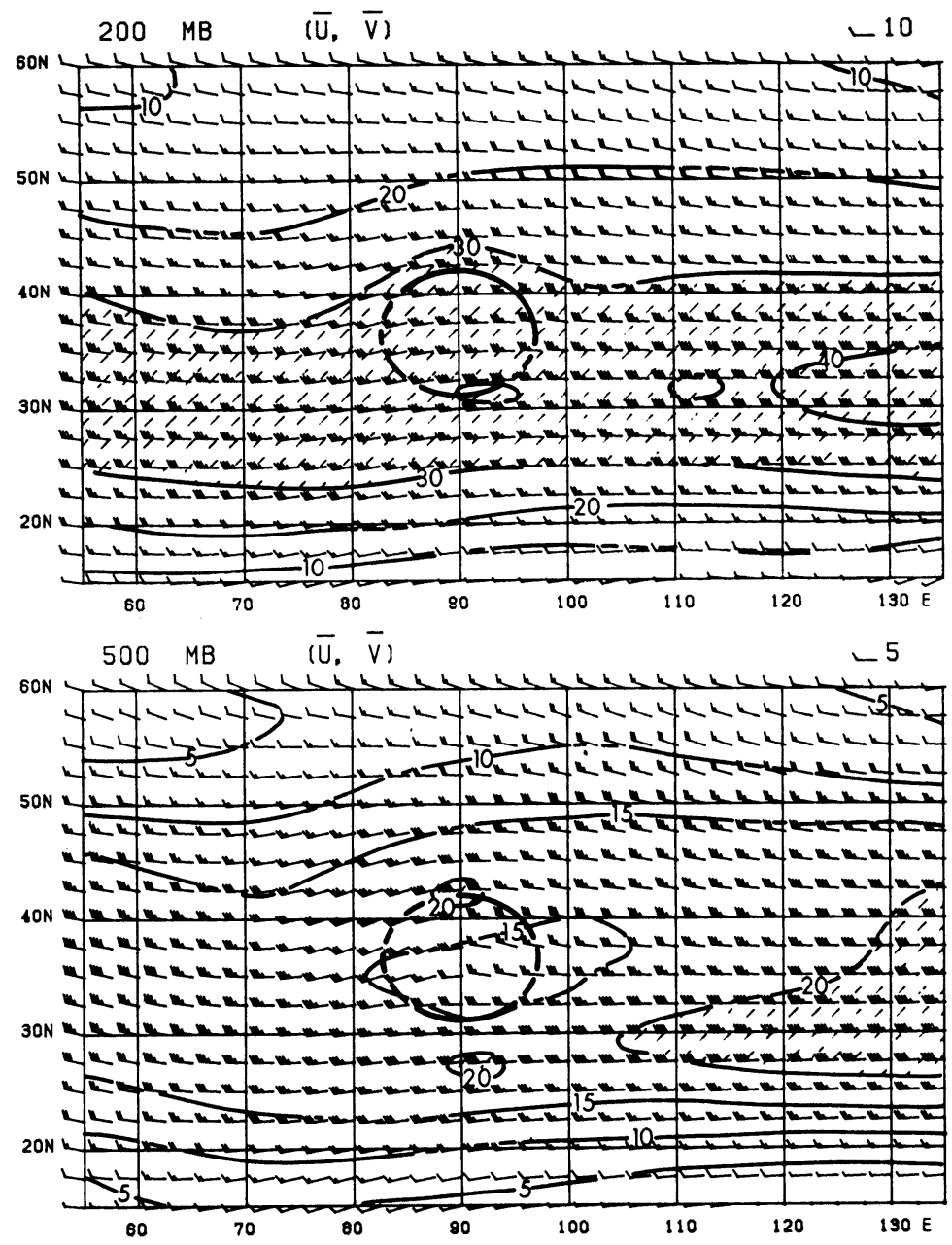

Fig. 3 As in Fig. 2, except for $200 \mathrm{mb}$ (top; half bar $\sim 5 \mathrm{~ms}^{-1}$ and full bar $\sim 10 \mathrm{~ms}^{-1}$ ), and $500 \mathrm{mb}$ (bottom; half bar $\sim 2.5 \mathrm{~ms}^{-1}$ and full bar $\sim 5 \mathrm{~ms}^{-1}$ ). Isotaches (full lines) are drawn at intervals of $10(5) \mathrm{ms}^{-1}$ at $200(500) \mathrm{mb}$. Heavy full lines indicate $3 \mathrm{~km}$ height contour of the mountain. 


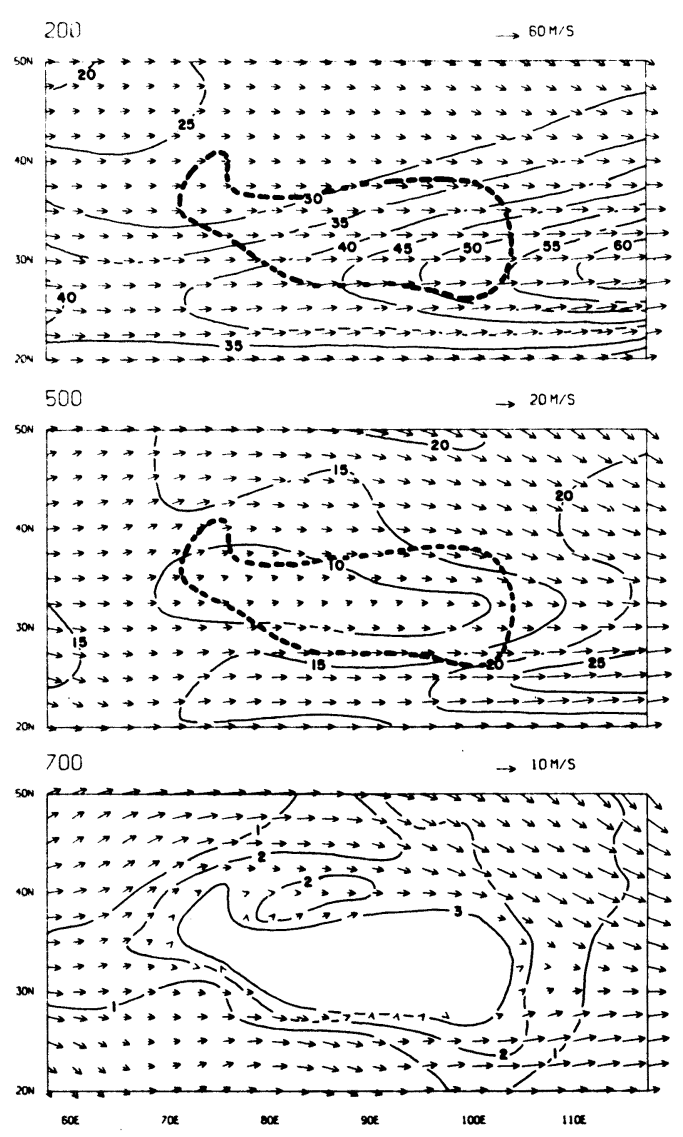

Fig. 4 1978-79 winter mean wind vectors over and around the Tibetan Plateau (from $\mathrm{Mu}$ rakami, 1981a). Top: At $200 \mathrm{mb}$ with isotach (full lines) intervals of $5 \mathrm{~ms}^{-1}$. Heavy dashed lines indicate the topographic height contour of $3 \mathrm{~km}$. Middle: As in the top, except at $500 \mathrm{mb}$. Bottom: At $700 \mathrm{mb}$. Full lines are for the smoothed topographic height contours at $1 \mathrm{~km}$ intervals.

properly, the weakening of the flow is not as pronounced as that in the real atmosphere. The low elevation of the mountain in the model may be another reason for the stronger flow at $500 \mathrm{mb}$.

At $200 \mathrm{mb}$ (Fig. 3, top), the westerly jet flows at approximately $30^{\circ} \mathrm{N}$ along the southern periphery of the mountain with an intensity of $35 \mathrm{~ms}^{-1}$ to $40 \mathrm{~ms}^{-1}$. The position of jet axis agrees well with that of the observational data (Fig. 4, top). In the observational data there is a strong eastward acceleration of the jet to the east of $70^{\circ} \mathrm{E}$. Estimating the magnitude of each term in the time mean zonal wind equation, Murakami (1981a) showed that this acceleration is due to nongeostrophic southerly flows associated with the thermally direct, local Hadley circulation with its upward motion over Malaysia and Indonesia, and downward motion over Siberia and northern China. There is no such acceleration of the jet in the model because it does not include the effects of continental and oceanic heat contrast and equatorial rainfall.

The 16-day mean vorticity fields at 850,700 , 500 , and $200 \mathrm{mb}$ are shown in Figs. 5 and 6 , respectively. In the lower troposphere (850 and $700 \mathrm{mb}$ ), positive vorticity extends along the southern periphery of the mountain, and negative vorticity along the northern boundary. This feature is similar to the observational data (see Fig. 8 of Murakami, 1981a). At $500 \mathrm{mb}$ (Fig. 6, bottom), we also find a vorticity pair near the mountain. At this level, anticyclonic vorticity is located immediately above the center of the mountain. This may suggest that the well-known Taylor column mechanism (Taylor, 1923) works on the smooth mountain. At $200 \mathrm{mb}$ (Fig. 6, top), there is a weak anticyclonic vorticity over
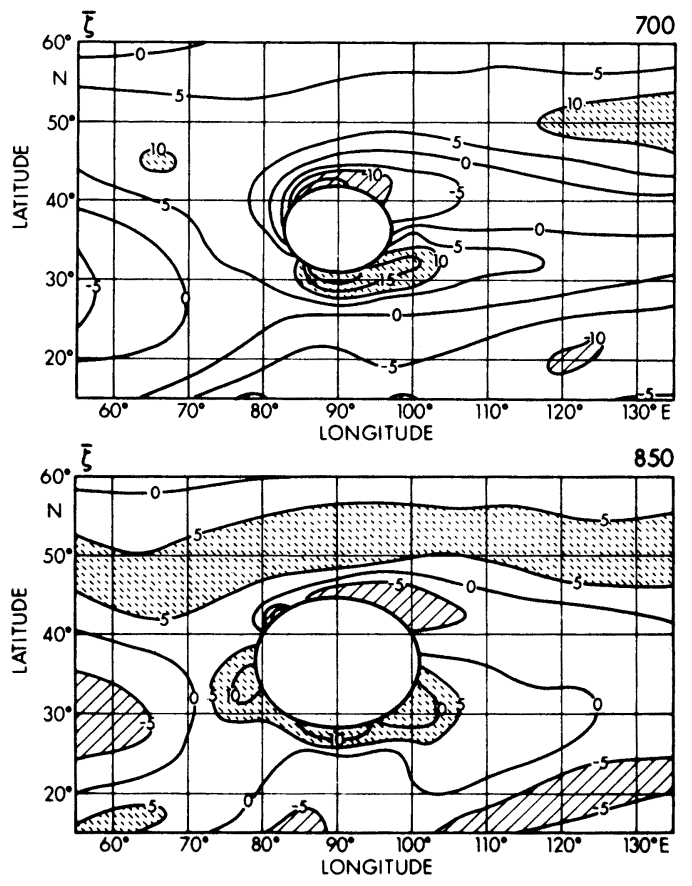

Fig. 5 16-day mean vorticity (unit; $10^{-6} \mathrm{~s}^{-1}$ ) at intervals of 5 units. Top: At $700 \mathrm{mb}$. Hatching (dashed hatching) indicates regions of less (greater) than $-10(+10)$ units. Bottom: At $850 \mathrm{mb}$. Regions of less (greater) than $-5(+5)$ units are hatched (dashed hatched). 

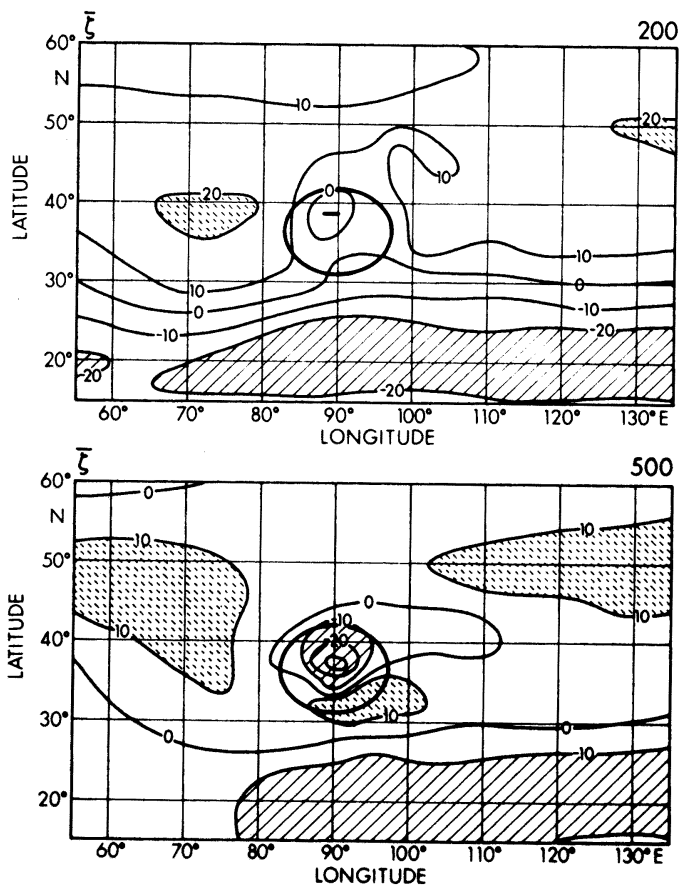

Fig. 6 16-day mean vorticity (unit; $10^{-6} s^{-1}$ ). Intervals are 10 units. Top: At $200 \mathrm{mb}$. Hatching (dashed hatching) indicates regions of less (greater) than $-20(+20)$ units. Bottom: At $500 \mathrm{mb}$. Regions of less (greater) than $-10(+10)$ are hatched (dashed hatched).

the mountain, presumably indicating that the Taylor column effect reaches up to $200 \mathrm{mb}$. Thus, the mountain has some control on the flow in the upper troposphere. Murakami (1981a) confirmed that the Taylor column effect exists in the observed winter mean circulation fields.

Another interesting feature at $200 \mathrm{mb}$ is an east-west extended zone of strong vorticity gradient between $25^{\circ} \mathrm{N}$ and $30^{\circ} \mathrm{N}$. This is south of the jet axis. Thus, the cumulative $\beta$ effect, i.e., $\beta+\partial \bar{\zeta} / \partial y$, may be large around these latitudes, and it may have some influence on the phase speed of the transient disturbances. This point will be discussed in Part II.

\section{Kinetic energy of transient eddies}

\subsection{Time mean of eddy kinetic energy}

We define eddy kinetic energy for transient eddies as

$$
K^{\prime}=\frac{1}{2}\left(u^{\prime 2}+v^{\prime 2}\right),
$$

Figs. 7 and 8 show 16-day mean $\overline{K^{\prime}}$ at 850,700 ,
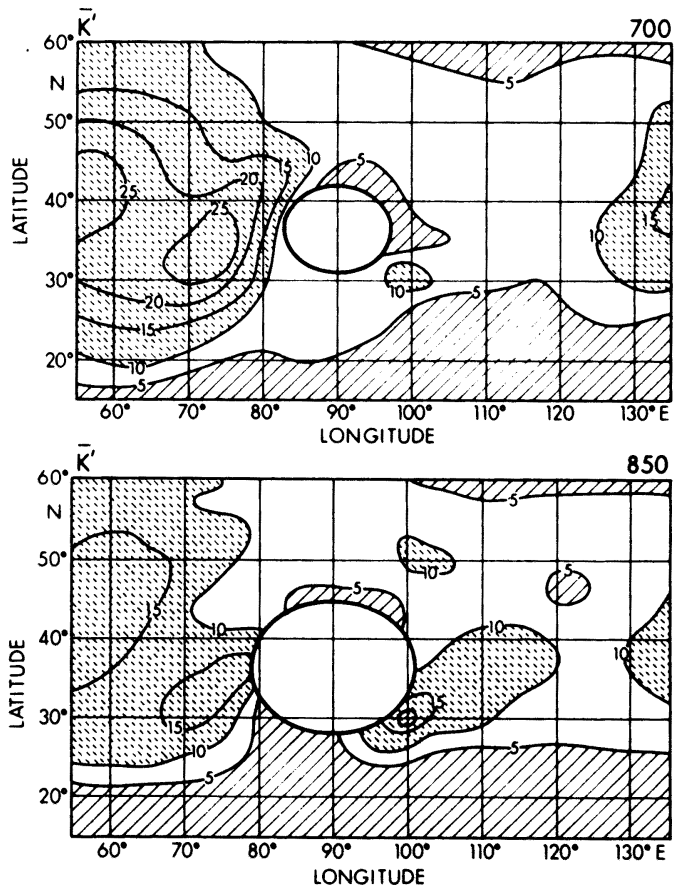

Fig. 7 16-day mean transient eddy kinetic energy (unit; $\mathrm{m}^{2} \mathrm{~s}^{-2}$ ) at 700 (top) and 850 (bottom) $\mathrm{mb}$. Isolines are for 5 units. Hatching (dashed hatching) indicates regions of less (greater) than 5 (10) units.

500 , and $200 \mathrm{mb}$, respectively. At $850 \mathrm{mb}$ (Fig. 7 , bottom), eddy kinetic energy is large (15 units) to the west and east, and small (5 units) north and south of the mountain. This clearly indicates that the mountain has strong blocking effects on transient disturbances. Fig. 9 shows the standard deviation of 3.5-5.5 day filtered $v$ fluctuations, computed by Murakami (1981b) at $700 \mathrm{mb}$ and $200 \mathrm{mb}$, respectively. We find the pattern of $\overline{K^{\prime}}$ at $850 \mathrm{mb}$ in the model similar to that of observed $\sigma(v)$ at $700 \mathrm{mb}$ (Fig. 9, bottom). An interesting feature at $850 \mathrm{mb}$ in the model is the large (20 units) maximum near southeast periphery of the mountain, which extends about $2000 \mathrm{~km}$ to the east. However, at $700 \mathrm{mb}$ (Fig. 7, top) there is only a very weak (10 units) maximum at southeast periphy. Thus, one may speculate that the large $\overline{K^{\prime}}$ in the downstream at $850 \mathrm{mb}$ reflects strong activity of lowlevel disturbances in the shallow layer below $700 \mathrm{mb}$. A large standard deviation limited in the lower atmosphere to the east of the Tibetan Plateau is also observed in Murakami (1981b) (refer to Fig. 4 of his paper). 

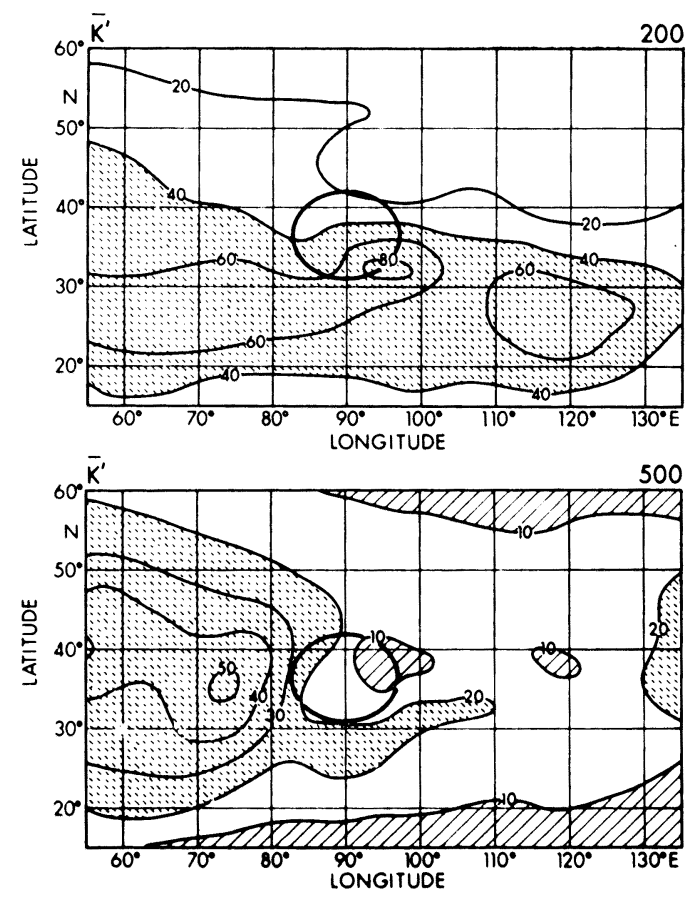

Fig. 8 16-day mean transient eddy kinetic energy (unit; $\mathrm{m}^{2} \mathrm{~s}^{-2}$ ). Top: At $200 \mathrm{mb}$ with intervals of 20 units. Dashed hatching indicates regions of greater than 40 units. Bottom: At $500 \mathrm{mb}$ with intervals of 10 units. Hatching (dashed hatching) indicates regions of less (greater) than $10(20)$ units.

Except in downstream areas, $\overline{K^{\prime}}$ pattern at $700 \mathrm{mb}$ (Fig. 7, top) is quite similar to that at $850 \mathrm{mb}$. There is a large $\overline{K^{\prime}}$ area to the west and a weak $\overline{K^{\prime}}$ area around the mountain. The large $\overline{K^{\prime}}$ gradient near the western periphery means that disturbances weaken rapidly as they approach the mountain from the west.

Eddy kinetic energy at $500 \mathrm{mb}$ is weak $(\sim 10$ units) over the mountain, while it is large (50 units) in the upstream area (Fig. 8, bottom). There is a zone with relatively large $\overline{K^{\prime}}(20$ units) at around $30^{\circ} \mathrm{N}$, which extends from $80^{\circ} \mathrm{E}$ to $110^{\circ} \mathrm{E}$. This may correspond to a zone of large standard deviation to the south of the Tibetan Plateau (see Fig. 4 of Murakami, 1981b).

The $200 \mathrm{mb}$ pattern of eddy kinetic energy (Fig. 8, top) shows that a band of large kinetic energy (60 units) lies along $30^{\circ} \mathrm{N}$, i.e., just along the westerly jet axis. This band may correspond to the southern band of large standard deviation of observed $v^{\prime}$ at $200 \mathrm{mb}$ shown in Fig. 9 (top). There is another band of large standard devia- $\sigma$ (v)

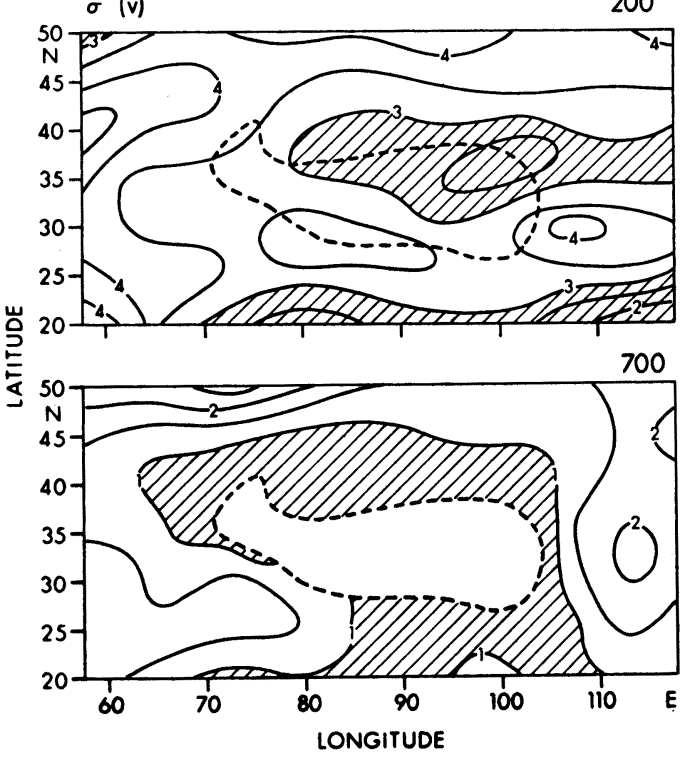

Fig. 9 Standard deviation (interval: $0.5 \mathrm{~ms}^{-1}$ ) of 3.5-5.5 day filtered, meridional winds at 200 (top) and 700 (bottom) $\mathrm{mb}$, respectively, for the 1978-79 winter (from Murakami, 1981b). Hatching denotes regions of less than $3(1) \mathrm{ms}^{-1}$ at $200(700) \mathrm{mb}$.

tion along $50^{\circ} \mathrm{N}$ in the observational data. The present experiment fails to reproduce this northern branch. The reason is not clear.

Here, it should be mentioned that eddy kinetic energy in the experiment is considerably larger than that of Murakami (1981b). Murakami composited 17 cases of 3.5-5.5 day filtered perturbations during the 90-day period of the 1978-79 winter. Of these 17 cases of compositing, ten disturbances were weaker than the seasonal mean, although seven disturbances were above normal. In comparison, the present study focuses only on strong disturbances that occurred during the selected 16-day period.

\subsection{Barotropic conversion term}

To further investigate the nature of transient disturbances, we present some of the terms in eddy kinetic energy equation, which are defined in Appendix IV. Figures 10 and 11 depict $\left(\overline{u^{\prime} u^{\prime}}\right.$, $\left.\overline{u^{\prime} v^{\prime}}\right)$-momentum flux vectors due to transient eddies, together with isotachs of 16-day mean winds at $850,700,500$, and $200 \mathrm{mb}$, respectively. In the upstream area of the mountain $\left(\overline{u^{\prime} u^{\prime}}, \overline{u^{\prime} v^{\prime}}\right)$ momentum fluxes are directed northeastward, that is, up the gradient of the 16-day mean isotachs, at 850,700 , and $500 \mathrm{mb}$. This indicates 

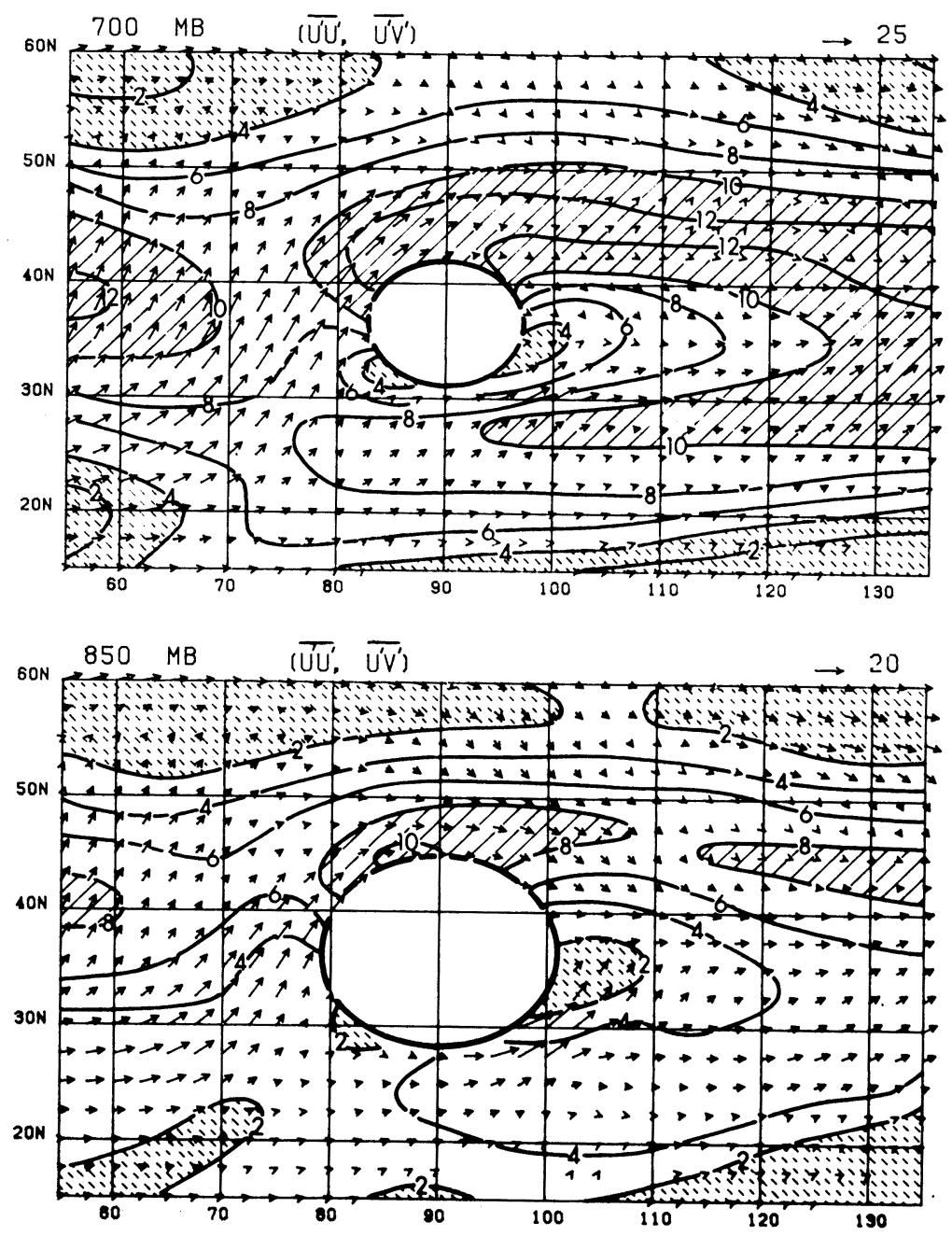

Fig. 10 16-day mean $\left(\overline{u^{\prime} u^{\prime}}, \overline{u^{\prime} v^{\prime}}\right)$-momentum fluxes due to transient eddies at $700 \mathrm{mb}$ (top; unit vector $25 \mathrm{~m}^{2} \mathrm{~s}^{-2}$ ) and $850 \mathrm{mb}$ (bottom; unit vector $20 \mathrm{~m}^{2} \mathrm{~s}^{-2}$ ), respectively. Also shown are isotaches (full lines) for 16-day mean winds. Refer to Fig. 2 for further information.

that, at these levels, transient eddies lose kinetic energy to 16-day time mean westerly flows, which is consistent with the fact that eddy kinetic energy decreases rapidly when approaching the mountain in the upstream area (Figs. 7 and 8).

At $850 \mathrm{mb}$ (Fig. 10, bottom), convergence of the northeastward $\left(\overline{u^{\prime} u^{\prime}}, \overline{u^{\prime} v^{\prime}}\right)$-momentum flux along the northern boundary of the mountain may contribute to the intensification of the northern branch of the westerly jet. At the southeast corner of the mountain a strong northeastward momentum flux flows down the gradient of 16-day mean winds.
The features at $700 \mathrm{mb}$ are similar to those at $850 \mathrm{mb}$. However, northeastward momentum flux is weak at the southeast corner of the mountain. At $500 \mathrm{mb}$ (Fig. 11, bottom), $\left(\overline{u^{\prime} u^{\prime}}\right.$,

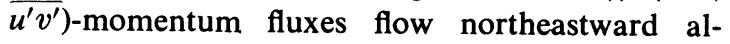
most everywhere between $20^{\circ} \mathrm{N}$ and $45^{\circ} \mathrm{N}$. Near the southern periphery of the mountain, the northeastward momentum flux is downgradient, implying that transient eddies extract kinetic energy from 16-day mean winds. We note a similar pattern at $200 \mathrm{mb}$.

The barotropic conversion terms between 16day mean kinetic energy and transient eddy kinetic energy $I\left(\bar{K}, K^{\prime}\right)$ are shown in Figs. 12 

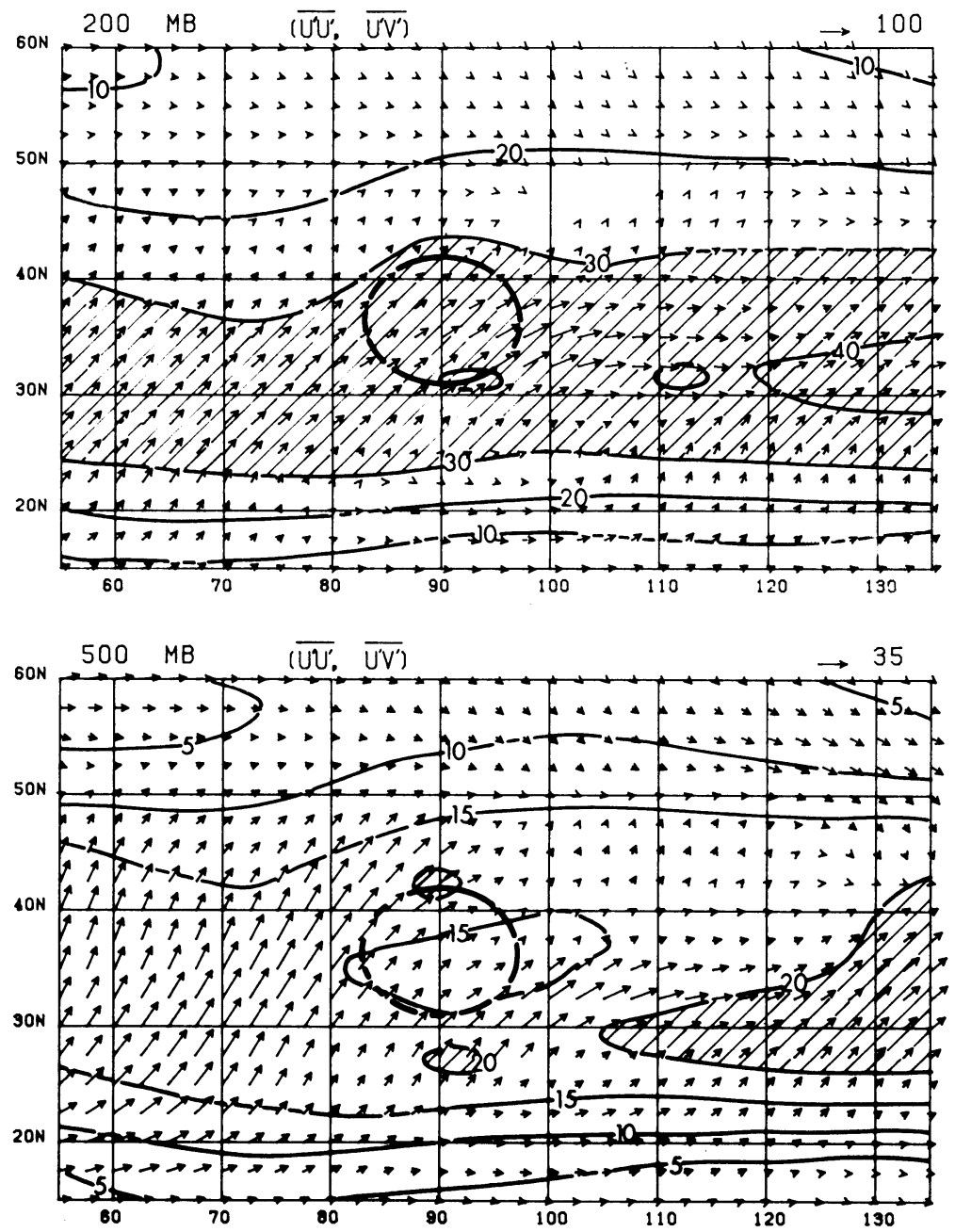

Fig. 11 As in Fig. 10, except at $200 \mathrm{mb}$ (top; unit vector $100 \mathrm{~m}^{2} \mathrm{~s}^{-2}$ ) and $500 \mathrm{mb}$ (bottom; unit vector $35 \mathrm{~m}^{2} \mathrm{~s}^{-2}$ ). Isotach (full lines) intervals for 16-day mean winds are the same as in Fig. 3.

13. The form of $I\left(\bar{K}, K^{\prime}\right)$ is given in Appendix IV. As suggested before, $I\left(\bar{K}, K^{\prime}\right)$ is negative in the upstream at $850 \mathrm{mb}$ (Fig. 12, bottom). This means that transient disturbances lose kinetic energy to 16-day mean winds. There are two maxima $I\left(\bar{K}, K^{\prime}\right)$ located at the northeast and southeast corners of the mountain. They correspond to regions of downgradient flow of $u^{\prime}$ momentum flux by transient eddies. This indicates that the barotropic conversion process may make some contribution to the intensification of low-level disturbances near the northeast and southeast corners of the mountain. In this vicinity, $700 \mathrm{mb} I\left(\bar{K}, K^{\prime}\right)$ is much smaller than the corresponding $850 \mathrm{mb}$ value, indicating the dis- turbances are trapped in the lower troposphere below about $850 \mathrm{mb}$.

At $500 \mathrm{mb}$ (Fig. 13, bottom), $I\left(\bar{K}, K^{\prime}\right)$ is negative almost everywhere between $20^{\circ} \mathrm{N}$ and $40^{\circ} \mathrm{N}$, except over the mountain. Thus, transient eddies furnish kinetic energy to the 16-day mean westerly jets around these latitudes. In contrast, positive $I\left(\bar{K}, K^{\prime}\right)$ over the mountain implies the redistribution of kinetic energy from the 16-day mean fields to transient eddies. Thus, smallness of $500 \mathrm{mb}$ eddy kinetic energy over the mountain (Fig. 8, bottom) must be due to some other process, such as, frictional dissipation and form drag of the mountain.

At $200 \mathrm{mb}$, zone of negative $I\left(\bar{K}, K^{\prime}\right)$ lies be- 

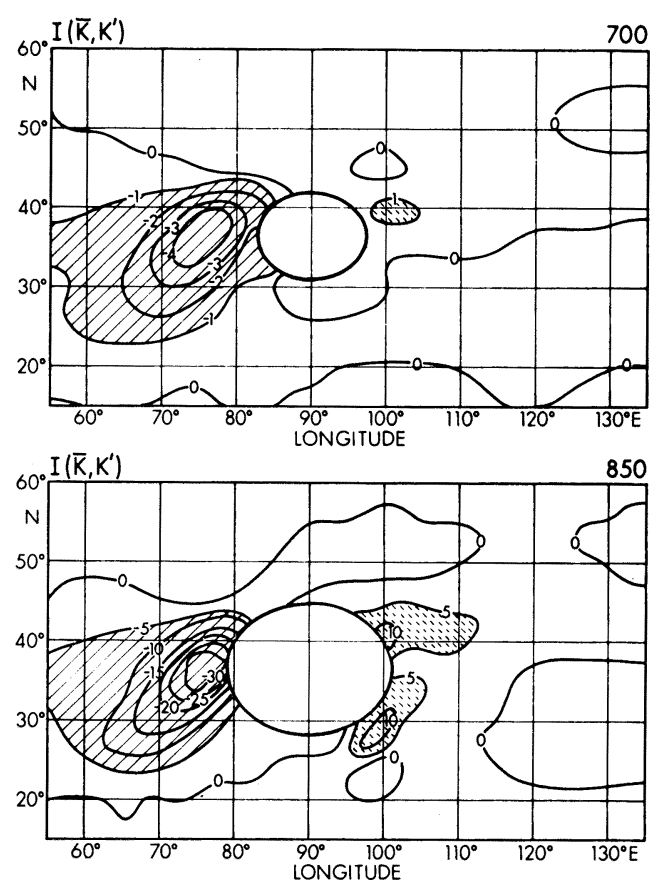

Fig. 12 16-day mean barotropic interaction term $I\left(\bar{K}, K^{\prime}\right)$. Top: At $700 \mathrm{mb}$ (unit; $10^{-4}$ $\mathrm{m}^{2} \mathrm{~s}^{-3}$ ). Hatching (dashed hatching) denotes regions of less (greater) than -1 (+1) unit. Bottom: At $850 \mathrm{mb}$ (unit; $10^{-5}$ $\mathrm{m}^{2} \mathrm{~s}^{-3}$ ). Hatching (dashed hatching) signifies regions of less (greater) than $-5(+5)$ units.

tween $15^{\circ}$ and $30^{\circ} \mathrm{N}$. These latitudes are south of the westerly jet axis where $\left(\overline{u^{\prime} u^{\prime}}, \overline{u^{\prime} v^{\prime}}\right)$-momentum fluxes flow up $\bar{u}$-gradient, feeding kinetic energy to the westerly jet. North of $30^{\circ} \mathrm{N}$, $I\left(\bar{K}, K^{\prime}\right)$ is generally small and negligible, except around the mountain. This is congruent with weak activity of disturbances in the higher latitudes (see Fig. 8, top). $I\left(\bar{K}, K^{\prime}\right)$ is positive over mountain with maximum (12 units) at the southeastern end. This positive $I\left(\bar{K}, K^{\prime}\right)$ suggests that transient eddies change their structures, such as, the horizontal tilt of their axis so that they can receive kinetic energy from 16-day mean winds to compensate for the loss of energy above the mountain.

\subsection{Pressure work term}

Figures 14 and 15 depict the pressure work term $-\overline{v^{\prime} \cdot \nabla \Phi^{\prime}}$ and its contributing term,

$$
-\frac{R}{p} \overline{\omega^{\prime} T^{\prime}},-\nabla \cdot \overline{v^{\prime} \Phi^{\prime}}, \text { and }-\frac{\partial}{\partial p} \overline{\omega^{\prime} \Phi^{\prime}}
$$

at $850 \mathrm{mb}$, respectively. The term $-(R / p) \overline{\omega^{\prime} T^{\prime}}$
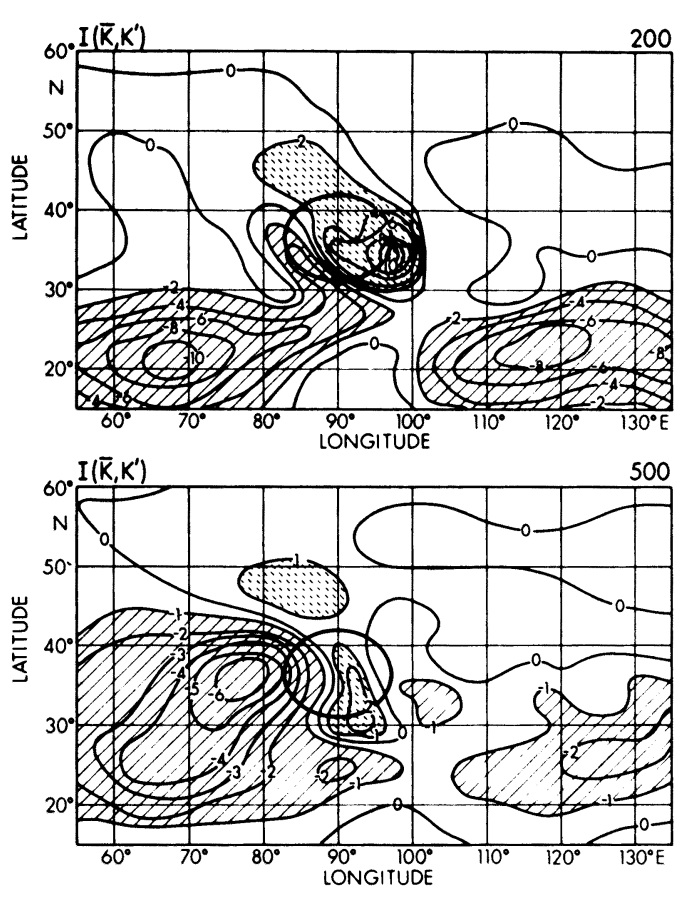

Fig. 13 16-day mean barotropic interaction term $I\left(\bar{K}, K^{\prime}\right)$ in units of $10^{-4} \mathrm{~m}^{2} \mathrm{~s}^{-3}$. Top: At $200 \mathrm{mb}$ with intervals of 2 units. Hatching (dashed hatching) indicates regions of less (greater) than $-2(+2)$ units. Bottom: At $500 \mathrm{mb}$ with intervals of 1 unit. Regions of less (greater) than $-1(+1)$ unit are hatched (dashed hatched).

denotes baroclinic conversion between transient eddy available potential energy and eddy kinetic energy, while $-\overline{\boldsymbol{V} \cdot \boldsymbol{v}^{\prime} \Phi^{\prime}}$ represents horizontal flux convergence of geopotential energy by transient eddies, and $-(\partial / \partial p) \overline{\omega^{\prime} \Phi^{\prime}}$ is its vertical flux convergence.

At $850 \mathrm{mb},-\overline{v^{\prime} \cdot \nabla \Phi^{\prime}}$ has two maxima at the mountain border, one on the west ( 8 units) and the other to the east (6 units). The location of the maximum in the west coincides well with maximum of eddy kinetic energy and negative maximum $I\left(\bar{K}, K^{\prime}\right)$ conversion (see Fig. 7, bottom and Fig. 12, bottom). Thus, eddy kinetic energy generated through the pressure work term is partly converted to the 16-day mean kinetic energy by the $I\left(\bar{K}, K^{\prime}\right)$ term in the upstream area. By examining each contributing term to the net pressure work, we find that $-\nabla \cdot \overline{v^{\prime} \Phi^{\prime}}$ contributes the most (6 units) to the maximum of $-\overline{v^{\prime} \cdot \nabla \Phi^{\prime}}$ (8 units) at the western border, although the baroclinic conversion term $-(R / p) \overline{\omega^{\prime} T^{\prime}}$ is also large there (4 to 6 units). The $-(\partial / \partial p) \overline{\omega^{\prime} \Phi^{\prime}}$ 

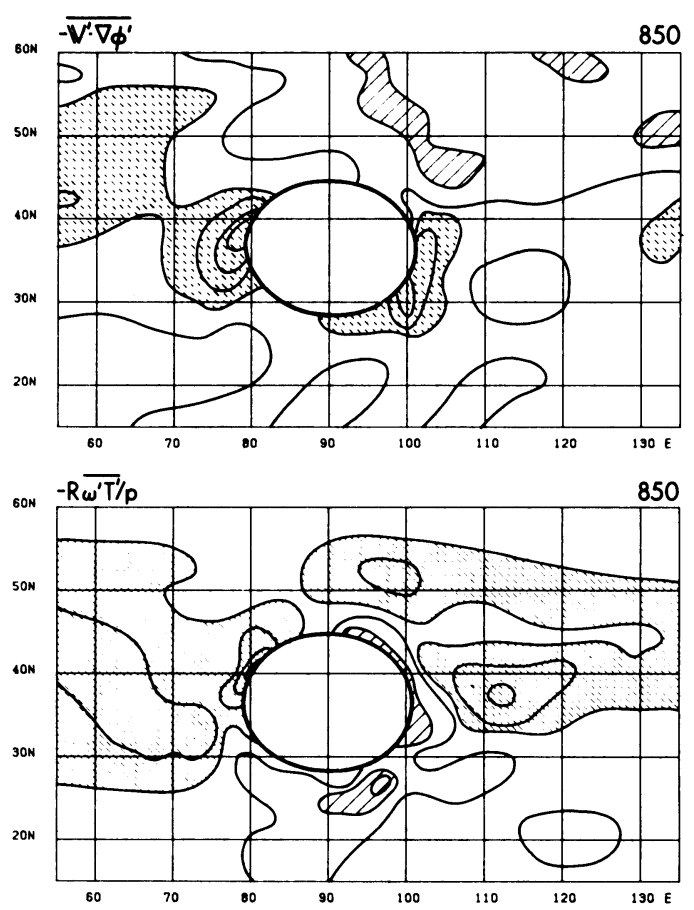

Fig. 14 16-day mean $-\nabla \cdot \overline{v^{\prime} \Phi^{\prime}}$ (top) and $-R \overline{\omega^{\prime} T^{\prime}} / p$ (bottom) due to transient eddies at $850 \mathrm{mb}$, in units of $10^{-4} \mathrm{~m}^{2} \mathrm{~s}^{-3}$. Contours are drawn at intervals of 2 units. Hatching (dashed hatching) denotes regions of less (greater) than $-2(+2)$ units.

effect contributes negatively to the pressure work term. Thus, at the western border, eddy kinetic energy is supplied primarily by the convergence of the horizontal flux of geopotential energy, and lost by the other processes, such as, barotropic conversion and vertical flux divergence of eddy geopotential energy.

The maximum of $-\overline{v^{\prime} \cdot \nabla \Phi^{\prime}}$ at $850 \mathrm{mb}$ near the southeastern border coincides well with the maximum of $K^{\prime}$ and positive maximum of $I\left(\bar{K}, K^{\prime}\right)$. However, note that the magnitude of $-\overline{v^{\prime} \cdot \nabla \Phi^{\prime}}\left(6 \times 10^{-4} \mathrm{~m}^{2} \mathrm{~s}^{-3}\right)$ is much larger than that of $I\left(\bar{K}, K^{\prime}\right) \quad\left(1 \times 10^{-4} \mathrm{~m}^{2} \mathrm{~s}^{-3}\right)$. Therefore, low-level disturbances at the eastern corner of the mountain are induced primarily by the pressure work term. In Fig. 14 (bottom), baroclinic conversion is negative along the eastern border. Thus, baroclinic instability cannot explain the generation of low-level disturbances there. One can see that $-(\partial / \partial p) \overline{\omega^{\prime} \Phi^{\prime}}$ is also slightly negative near the eastern border of the mountain. The only contributor feeding eddy kinetic energy at the eastern periphery is the $-\nabla \cdot \overline{v^{\prime} \Phi^{\prime}}$ term
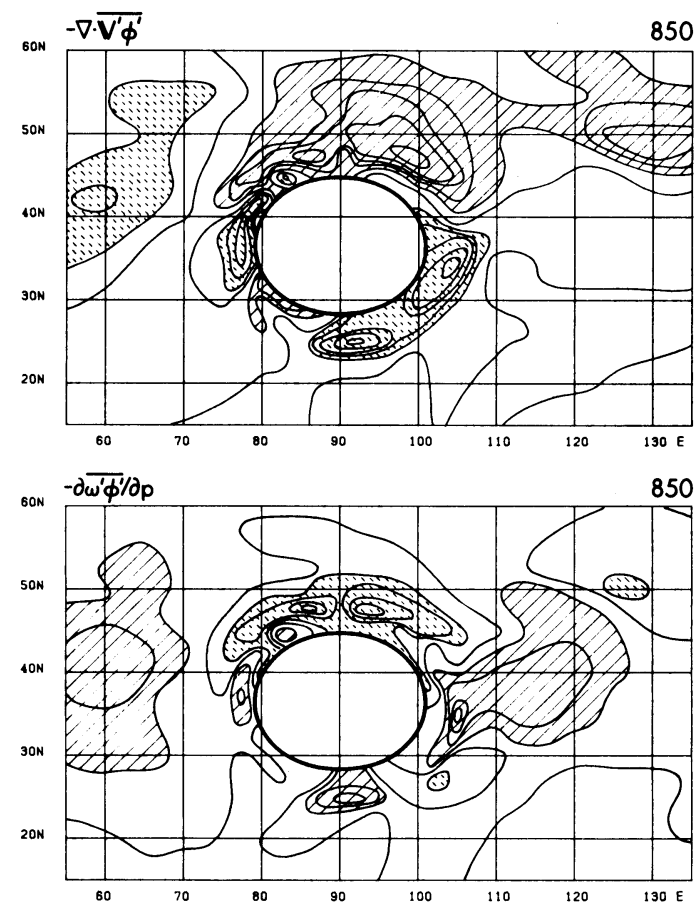

Fig. 15 16-day mean $-\nabla \cdot \overline{v^{\prime} \Phi^{\prime}}$ (top) and $-\partial \overline{\omega^{\prime} \Phi^{\prime}} / \partial p$ (bottom) due to transient eddies at $850 \mathrm{mb}$, in units of $10^{-4} \mathrm{~m}^{2} \mathrm{~s}^{-3}$. Contour intervals are for 2 units. Hatching (dashed hatching) indicates regions of less (greater) than $-2(+2)$ units.

(10 units). The pattern of $-\nabla \cdot \overline{v^{\prime} \Phi^{\prime}}$ shows divergence along the northern periphery and convergence along the eastern and southeastern periphery, suggesting that $\overline{v^{\prime} \Phi^{\prime}}$ flux is directed to the southeast along the northeastern periphery of the mountain. A comparison between $-\nabla \cdot \overline{v^{\prime}} \Phi^{\prime}$ and $-(\partial / \partial p) \overline{\omega^{\prime} \Phi^{\prime}}$ patterns reveals that positive $-(\partial / \partial p) \overline{\omega^{\prime} \Phi^{\prime}}$ nearly cancels negative $-\nabla \cdot \overline{v^{\prime} \Phi^{\prime}}$ to the north of the mountain. In this vicinity, downward flux convergence of geopotential energy $-(\partial / \partial p) \overline{\omega^{\prime} \Phi^{\prime}}$ largely compensates for the horizontal divergence of geopotential energy.

Far downstream at about $\left(115^{\circ} \mathrm{E}, 37^{\circ} \mathrm{N}\right)$, large negative $-(\partial / \partial p) \overline{\omega^{\prime} \Phi^{\prime}}$ is approximately compensated for by positive $-(R / p) \overline{\omega^{\prime} T^{\prime}}$. This indicates that kinetic energy supplied through baroclinic conversion from eddy available potential energy is not used to develop disturbances at $850 \mathrm{mb}$, but rather it is transported into the upper atmosphere. This, in turn, suggests that lowlevel disturbances generated in the downstream of the mountain may supply energy for the development of disturbances aloft. Part II details 
an exact mechanism of lee-cyclogenesis.

In Fig. 15 (top), note that regions of positive $-\nabla \cdot \overline{v^{\prime} \Phi^{\prime}}$ extend from the east to the south of the mountain, where it has another maximum $\left(10\right.$ units) at $25^{\circ} \mathrm{N}, 93^{\circ} \mathrm{E}$. The $-(R / p) \overline{\omega^{\prime} T^{\prime}}$ and $-(\partial / \partial p) \overline{\omega^{\prime} \Phi^{\prime}}$ terms have negative maximum south of the mountain. Murakami (1981b) showed that small-scal disturbances generated near the northeastern corner of the Tibetan Plateau propagate southward along the eastern periphery of the plateau, eventually reaching India where they dissipate.

At $500 \mathrm{mb}$ (Fig. 16, top), the pressure work term $-\overline{v^{\prime} \cdot \nabla \Phi^{\prime}}$ has a maximum (12 units) at $74^{\circ} \mathrm{E}, 38^{\circ} \mathrm{N}$ in the upstream. Its position coincides with that of maximum $\overline{K^{\prime}}$ and that of negative maximum $I\left(\bar{K}, K^{\prime}\right)$. This relationship is basically similar to that at $850 \mathrm{mb}$. The patterns over and downstream of the mountain are considerably different from those at $850 \mathrm{mb}$. A maximum of $-\overline{v^{\prime} \cdot \nabla \Phi^{\prime}}$ at southeastern edge is not as strong (6 units) as that in the upstream, but it is embedded in a weak positive belt which extends far downstream to a maximum at $130^{\circ} \mathrm{E}$, $35^{\circ} \mathrm{N}$. One can find that the major features of $-\overline{\boldsymbol{v}^{\prime} \cdot \nabla \Phi^{\prime}}$ are explained mostly by contributions of $-\nabla \cdot \overline{v^{\prime} \Phi^{\prime}}$. The magnitudes of the other two terms, $-(R / p) \overline{\omega^{\prime} T^{\prime}}$ and $(\partial / \partial p) \overline{\Phi^{\prime} \omega^{\prime}}$ are small
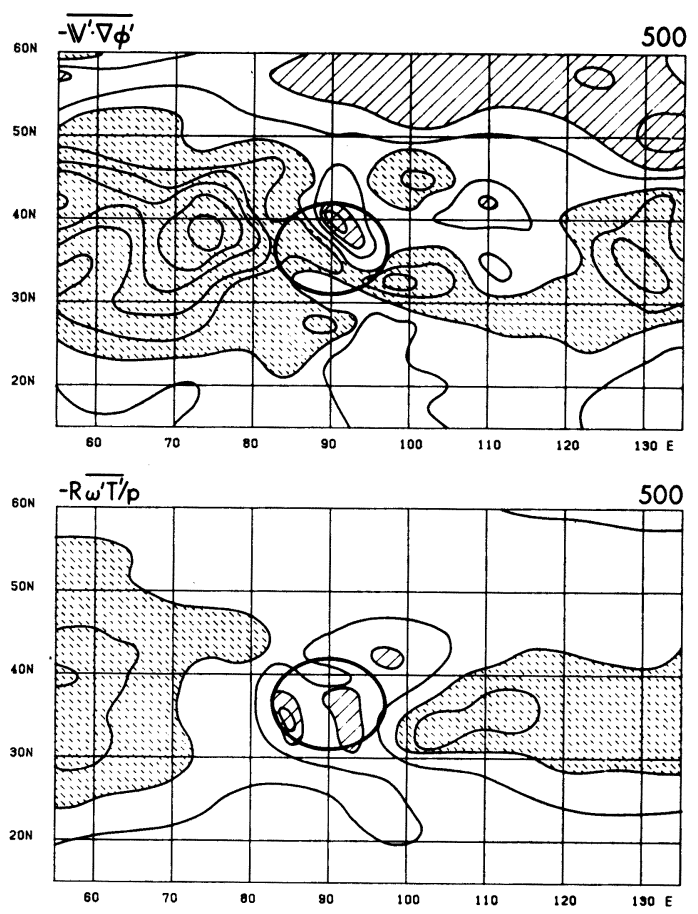

Fig. 16. As in Fig. 14, except at $500 \mathrm{mb}$.
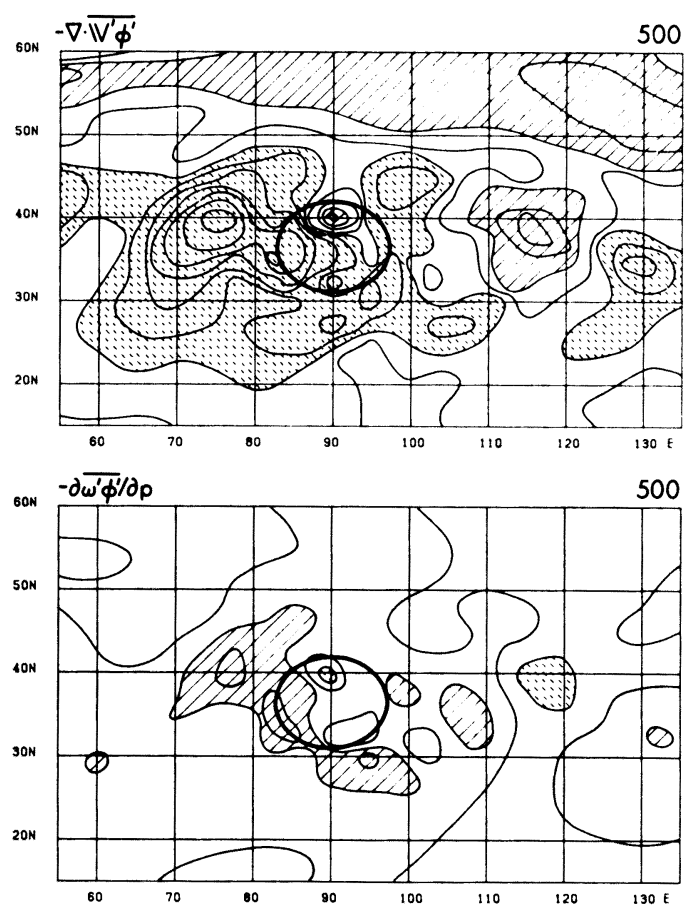

Fig. 17 As in Fig. 15, except at $500 \mathrm{mb}$.

compared with that of $-\nabla \cdot \overline{v^{\prime} \Phi^{\prime}}$.

It is interesting that $-(R / p) \overline{\omega^{\prime} T^{\prime}}$ at $500 \mathrm{mb}$ is negative over the mountain, implying that the mountain exerts a modifying effect on the structures of disturbances. Since the mountain interrupts rapid movement of disturbances in the lower troposphere, the axis of disturbances may tilt eastward with increasing height over the mountain. The $-(\partial / \partial p) \overline{\Phi^{\prime} \omega^{\prime}}$ term is negative and substantial near the mountain, indicating a downward flux divergence of geopotential energy near $500 \mathrm{mb}$.

At $200 \mathrm{mb}$, a positive zone of the pressure work term, $-\overline{\boldsymbol{v}^{\prime} \cdot \nabla \Phi^{\prime}}$, lies along $30^{\circ} \mathrm{N}$ (Fig. 18, top). This latitude corresponds to the position of the westerly jet axis and large eddy kinetic energy. In the mountain area, a maximum $-\overline{v^{\prime} \cdot \nabla \Phi^{\prime}}$ (10 units) over the southern section contrasts with a negative area extending southeastward from the northern part to the eastern section $\left(100^{\circ} \mathrm{E}, 35^{\circ} \mathrm{N}\right)$. Figure 19 (top) shows that the pattern of $-\nabla \cdot \overline{v^{\prime} \Phi^{\prime}}$ is almost a duplicate of the $-\overline{v^{\prime} \cdot \nabla \Phi^{\prime}}$ pattern. A comparison of Fig. 19 (top) with Fig. 13 (top) reveals an approximate inverse relationship between $-\nabla \cdot \overline{\boldsymbol{v}^{\prime} \Phi^{\prime}}$ and $I\left(\bar{K}, K^{\prime}\right)$ at $200 \mathrm{mb}$. This means that eddy kinetic energy generated through horizontal convergence of the geopotential energy flux is trans- 

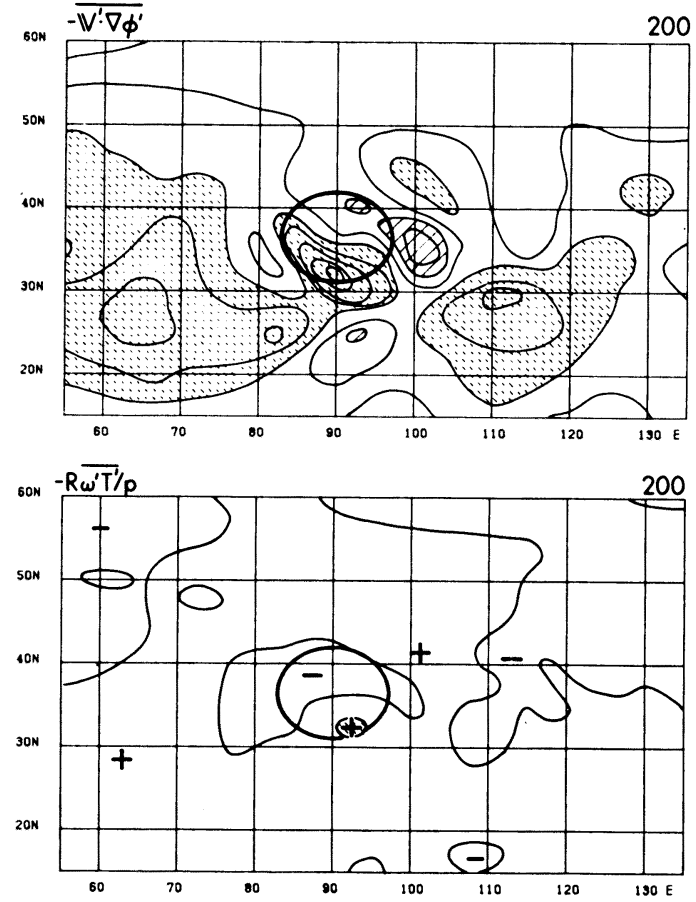

Fig. 18 As in Fig. 14, except at $200 \mathrm{mb}$ with intervals of 5 units. Hatching (dashed hatching) indicates regions of less (greater) than $-5(+5)$ units.

ferred into 16-day mean kinetic energy via the $I\left(\bar{K}, K^{\prime}\right)$ barotropic process.

Figure 18 (bottom) shows that $-(R / p) \overline{\omega^{\prime} T^{\prime}}$ is near zero at $200 \mathrm{mb}$. Therefore, baroclinic conversion contributes little to eddy activity at this level. Vertical flux convergence of geopotential energy $-(\partial / \partial p) \overline{\Phi^{\prime} \omega^{\prime}}$ is also small (Fig. 19, bottom), indicating a weak interaction with disturbances below $200 \mathrm{mb}$.

Figure 20 depicts the vertical flux of geopotential energy $\overline{\Phi^{\prime} \omega^{\prime}}$ at 850 and $500 \mathrm{mb}$. At $850 \mathrm{mb}$, downward fluxes are dominant around the mountain. This may compensate for the frictional dissipation of eddy kinetic energy near the mountain surface. At $500 \mathrm{mb}$, above and in the immediate vicinity of the mountain, $\overline{\Phi^{\prime} \omega^{\prime}}$ fluxes are also downward. This is contrasted with significant upward fluxes prevailing in the outer area. In the upper troposphere above $500 \mathrm{mb}$, the magnitude of $\overline{\Phi^{\prime} \omega^{\prime}}$ becomes small (not shown).

\section{Temperature perturbation}

Figure 21 (top) shows temperature variances of transient disturbances at $850 \mathrm{mb}$. The most
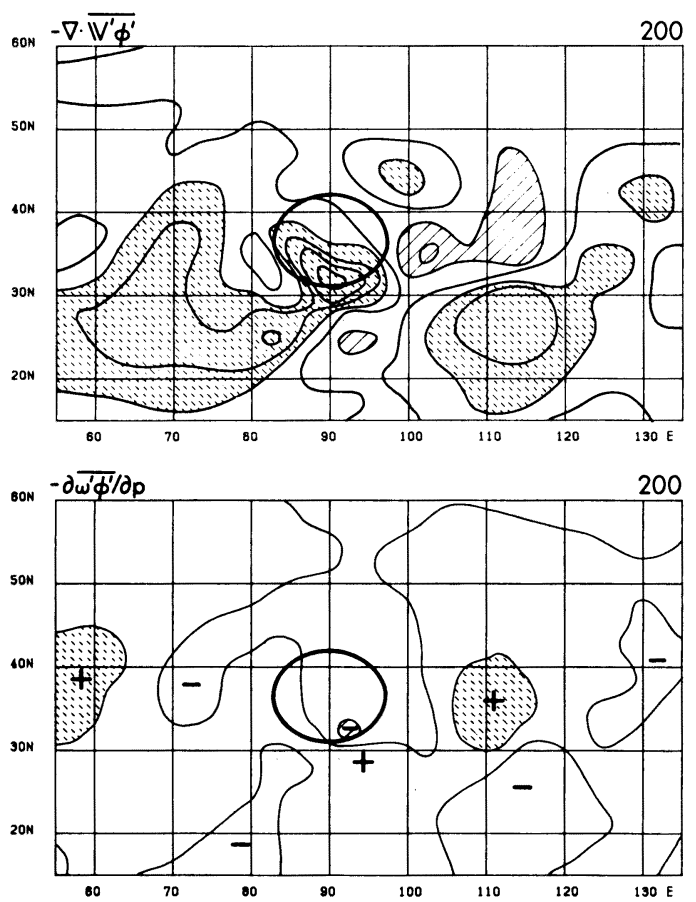

Fig. 19 As in Fig. 15, except at $200 \mathrm{mb}$. Refer to Fig. 18 for further information.

interesting feature is a belt of large temperature variances surrounding the mountain. It starts at $70^{\circ} \mathrm{E}, 35^{\circ} \mathrm{N}$ in the upstream, elongates along the northern periphery, then extends along the eastern side, ultimately reaching an area south of the mountain. Their amplitudes are about 20 to $30\left({ }^{\circ} \mathrm{C}\right)^{2}$, corresponding to $5^{\circ} \mathrm{C}$ standard deviations. Since temperature variances are small near the mountain at $700 \mathrm{mb}$ (not shown), the large temperature variances at $850 \mathrm{mb}$ are closely related to the low-level disturbance activity trapped around the mountain. Furthermore, a circular pattern of temperature variation suggests that these edge disturbances move clockwise around the mountain. This point will be elaborated on in Part II.

Figure 21 (bottom) depicts $I\left(\bar{A}, A^{\prime}\right)$, the energy conversion term between the 16-day mean and the transient eddy available potential energy at $850 \mathrm{mb}$. [See Appendix IV for the definition of $\left.I\left(\bar{A}, A^{\prime}\right)\right]$. One finds that large positive $I\left(\bar{A}, A^{\prime}\right)$ ( $>2.5$ units) lies along the eastern border from the northeast corner to the south of the mountain. In this region, the disturbances extract their eddy available potential energy through nonlinear interaction with the 16-day mean temperature fields. Note, however, that this eddy 

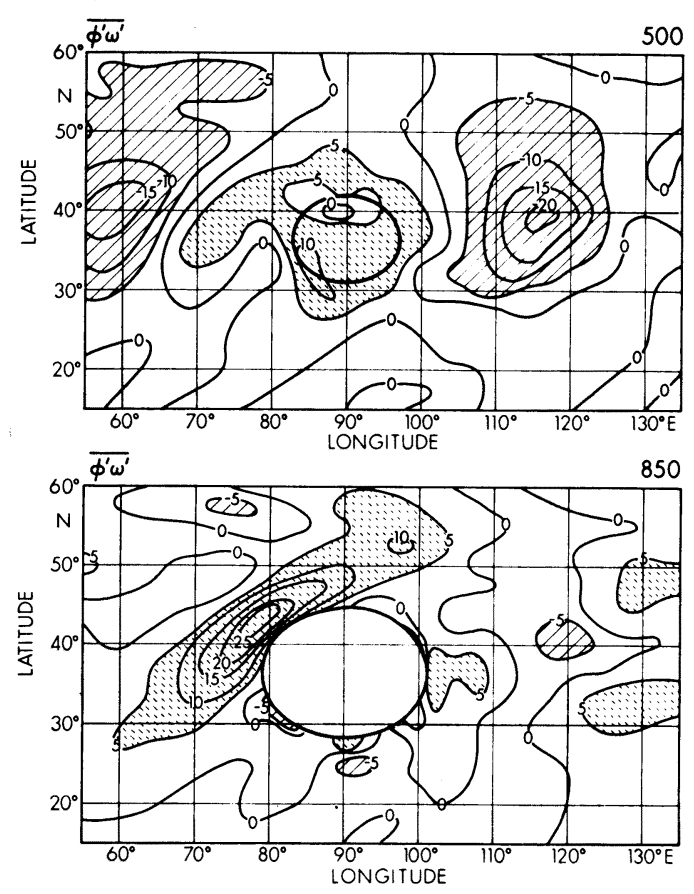

Fig. 20 16-day mean $\overline{\Phi^{\prime} \omega^{\prime}}$-geopotential fluxes due to transient eddies at $500 \mathrm{mb}$ (top) and $850 \mathrm{mb}$ (bottom), respectively. Intervals are for $5 \times 10^{-3} \mathrm{mb} \mathrm{m}^{2} \mathrm{~s}^{-3}$. Hatching (dashed hatching) denotes regions of less (greater) than $-5(+5) \times 10^{-3} \mathrm{mb} \mathrm{m}^{2} \mathrm{~s}^{-3}$.

available potential energy does not convert to eddy kinetic energy, but rather the opposite conversion occurs east and south of the mountain where $-R\left(\overline{\omega^{\prime} T^{\prime}}\right) / p$ is negative and substantial (Fig. 14, bottom).

Figure 22 demonstrates the distribution of eddy temperature flux vectors $\left(\overline{u^{\prime} T^{\prime}}, \overline{v^{\prime} T^{\prime}}\right)$ at 850 and $200 \mathrm{mb}$, respectively. Contours for the 16day mean temperature are also shown. Temperature transport by transient eddies is northward at both levels. There are two areas of large northward flux at $850 \mathrm{mb}$. One is located in the upstream area around $60^{\circ} \mathrm{E}, 45^{\circ} \mathrm{N}$. Along the eastern boundary of the mountain are strong northward directed temperature fluxes that originate around the southeast periphery. Apparently this northerly flux is related to low-level, edge disturbances developing along the eastern periphery of the mountain. Regions of strong northward fluxes extend eastward to about $120^{\circ} \mathrm{E}$, reflecting lee-cyclone activity downstream of the mountain (refer to the large kinetic energy at $850 \mathrm{mb}$ around $120^{\circ} \mathrm{E}, 38^{\circ} \mathrm{N}$ in Fig. 7, bottom). Part II will investigates the relationship between
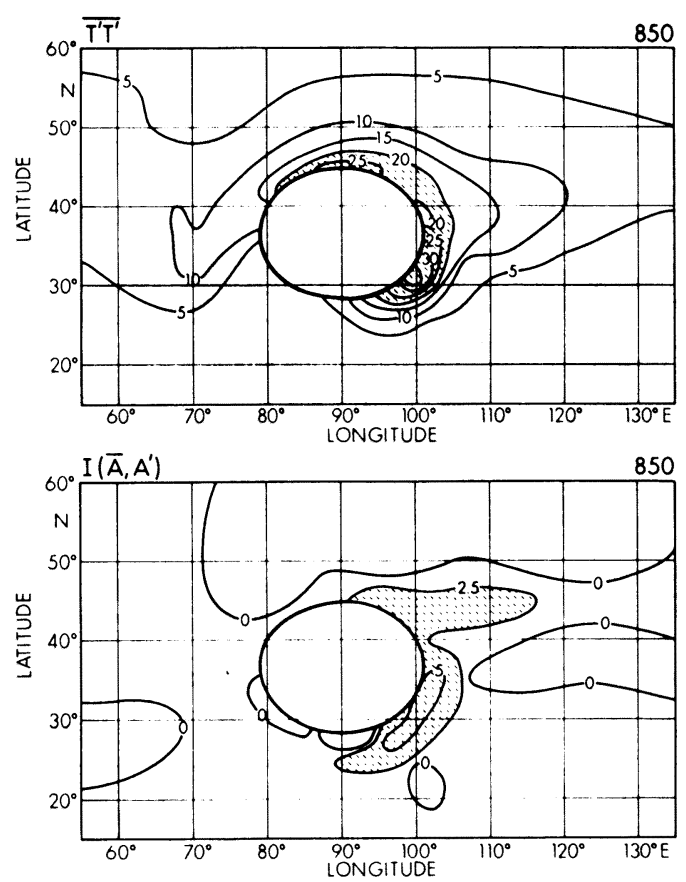

Fig. 21 Top: 16-day mean $\overline{T^{2}}$ temperature variance $\left({ }^{\circ} \mathrm{C}^{2}\right)$ due to transient eddies at $850 \mathrm{mb}$. Intervals are for 5 units. Dashed hatching denotes regions of greater than 20 units. Bottom: 16-day mean $I\left(\bar{A}, A^{\prime}\right)$ available potential energy conversion term $\left(10^{-5}{ }^{\circ} \mathrm{C} \cdot \mathrm{s}^{-1}\right)$ at $850 \mathrm{mb}$. Intervals are for 2.5 units. Dashed hatching denotes regions of greater than 2.5 units.

these lee-cyclogenesis far downstream from the mountain and the development of low-level, edge disturbances trapped close to the mountain.

At $200 \mathrm{mb}$, of particular interest is the low 16-day mean temperature over the mountain. This agrees well with Murakami (1981a), who found that temperatures are coldest over the western Tibetan Plateau (see Fig. 12 in his paper). Another interesting feature is the strong northward temperature transport by transient eddies over the mountain. Unfortunately, an exact relationship between the cold 16-day mean temperature and the strong eddy temperature fluxes above the mountain is not yet known.

\section{Conclusion}

A numerical experiment was performed with a simplified hemispheric general circulation model to investigate the mechanical effects of a mountain on transient disturbances. The model uses a finite-difference scheme based on 

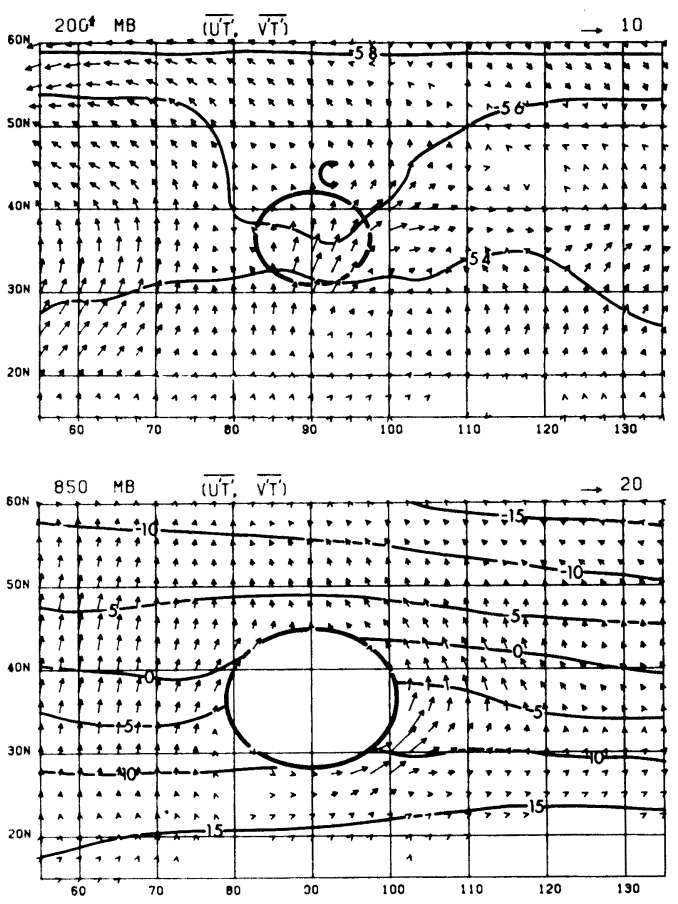

Fig. 22 16-day mean $\left(\overline{u^{\prime} T^{\prime}}, \overline{v^{\prime} T^{\prime}}\right)$-temperature fluxes (arrows), and 16-day mean $T$-temperature fields (full lines). Top: At $200 \mathrm{mb}$ with unit flux vector of $10^{\circ} \mathrm{C} \mathrm{ms}^{-1}$ and $T$ intervals of $2^{\circ} \mathrm{C}$. Bottom: At $850 \mathrm{mb}$; unit flux vector is $20^{\circ} \mathrm{C} \mathrm{ms}^{-1}$ and $T$ intervals are $5^{\circ} \mathrm{C}$.

the UCLA's general circulation model (Arakawa, 1972) and modified by Nakamura (1978a, b). It includes the following: convective adjustment, eddy vertical mixing of momentum, surface drag, and nonlinear horizontal viscosity. Basic zonal flows are governed by Newtonian cooling, which restores temperature fields to their observed winter mean temperature. The time integration was performed until day 72. However, analysis was done for a selected period of 16 days from day 21 to day 36, at which time some interesting phenomena occurred around the mountain.

The 16-day mean winds tend to flow around, rather than over the mountain in the lower atmosphere. The westerly jet splits into a northern and a southern branch in the upstream area. These branches flow along the mountain periphery and merge into one flow again at about $1000 \mathrm{~km}$ east of the mountain. An area of weak winds lies between the two branches downstream of the mountain. At $500 \mathrm{mb}$, winds are weak over the mountain and the jet stream's axes lie to the north and south of the mountain. At $200 \mathrm{mb}$ the westerly jet flows to the south of the mountain with no counterpart to the north. These simulated flow patterns agree very well with observed wintertime mean winds in the vicinity of the Tibetan Plateau (Staff Members, 1957; Murakami, 1981a). The 16-day mean vorticity is also similar to the observed vorticity. The Taylor column effect produced by the mountain has some influence up to $200 \mathrm{mb}$, congruent with Murakami's (1981a) finding. In general, the performance of our model is satisfactory in reproducing the winter mean circulation near the Tibetan Plateau.

Statistical aspects of transient disturbances were investigated. Eddy kinetic energy is large east and west of the mountain and weak around the mountain at $850 \mathrm{mb}$, which coincides with the results by Murakami (1981b). At $700 \mathrm{mb}$ eddy kinetic energy east of the mountain is small as compared with a distinct maximum at $850 \mathrm{mb}$. This suggests that low-level disturbances are generated and trapped below $700 \mathrm{mb}$ in the downstream of the mountain. Interestingly, pronounced low-level temperature perturbations at $850 \mathrm{mb}$ originate at the northwest periphery of the mountain and extend clockwise around the mountain until reaching the southern part of the mountain.

These low-level, edge disturbances receive their eddy available potential energy from 16-day mean temperature fields. Of particular interest is that their eddy available potentail energy is not converted into eddy kinetic energy, but rather the reverse process occurs in the disturbances. Namely, the baroclinic conversion process contributes. little to the development of edge disturbances trapped below $700 \mathrm{mb}$ along the eastern boundary of the mountain. The main contributor to the low-level, edge disturbances is the flux convergence of eddy geopotential energy, $-\nabla \cdot \overline{v^{\prime} \Phi^{\prime}}$. Barotropic conversion contributes too, but it is much smaller than $-\nabla \cdot \overline{v^{\prime} \Phi^{\prime}}$. Since $-\nabla \cdot \overline{v^{\prime} \Phi^{\prime}}$ is approximately zero for geostrophic flows, low-level edge disturbances acquire their kinetic energy by fluxes of geopotential energy due to ageostrophic eddy wind components. This point will be further elaborated on in Part II.

At $500 \mathrm{mb}$, eddy kinetic energy of transient disturbances is small over the mountain. Baroclinic conversion is negative over the mountain, indicating the reduction of eddy kinetic energy 
by conversion into the eddy available potential energy. In contrast, eddy kinetic energy tends to increase by receiving energy from the 16-day mean fields through barotropic interaction processes. Outside of the mountain area horizontal flux convergence of eddy geopotential energy and baroclinic conversion tend to increase eddy kinetic energy, though the latter is much smaller than the former.

At $200 \mathrm{mb}$, a band of large eddy kinetic energy lies along about $30^{\circ} \mathrm{N}$, which coincides with the position of westerly jet axis. Over the mountain, transient eddies receive a large amount of kinetic energy through barotropic interaction with the 16-day mean flows. This, together with the large northward sensible heat flux at $200 \mathrm{mb}$ over the mountain, suggests that the effect of the mountain reaches as high as the $200 \mathrm{mb}$ level. It is important to note that baroclinic conversion is negligible and the horizontal convergence of eddy geopotential energy flux is primarily responsible for the maintenance of eddy kinetic energy at $200 \mathrm{mb}$.

In Part I, evidence has been presented that the mountain exerts strong effects on transient disturbances. Part II will investigate the structure and behavior of particular disturbances that pass through the mountain region during the selected 16-day period.

\section{Acknowledgments}

The first author wishes to express his thanks to Drs. A. Kasahara and D. G. Branstator of the National Center for Atmospheric Research (NCAR) for their helpful discussions on performing numerical time integrations. The authors are indebted to Mrs. Dixie Zee for her assistance in data processing, computer programming, and final editing of the manuscript. They also thank Mr. Louis Oda for drafting the figures. Thanks are extended to Mrs. K. Kudo of the University of Tokyo; Mrs. S. A. Arita, and Ms. J. M. Maeda and S. N. H. Chock of the University of Hawaii for typing the manuscript.

The numerical integrations were conducted on a Cray-1 computer at NCAR, which is sponsored by the National Science Foundation, Washington, D.C. Most of the data analyses were performed at the University of Hawaii under research Grant No. ATM-820635, supported jointly by the National Science Foundation and the National Oceanic and Atmospheric Adminis- tration, Washington, D.C.

This research is also a part of the U.S.-Japan Cooperative Science Program on the "Influence of the earth's orography on the atmospheric general circulation", supported jointly by the National Science Foundation, U.S.A. and the Japan Society for the Promotion of Science, Japan.

\section{Appendix I: List of Symbols}

$\lambda, \phi:$ longitude and latitude

$p:$ pressure

$d x, d y: a \cos \phi d \lambda$ and $a d \phi ; a$, radius of earth $\nabla:\left(\frac{\partial}{\partial x}, \frac{\partial}{\partial y}\right)$

$u, v:$ zonal and meridional winds

$\omega$ : vertical $p$-velocity

$T:$ temperature

$\theta:$ potential temperature

$\Phi$ : geopotential height

$\alpha$ : specific volume

$\sigma:$ sigma coordinate

$p_{s}:$ surface pressure

$p_{t}:$ pressure at model's top

$\pi: p_{s}-p_{t}$

$\dot{\sigma}:$ vertical $\sigma$-velocity

$\kappa: R / c_{p} ; R$, gas constant and $c_{p}$ heat capacity of the air at constant pressure

$\boldsymbol{k}:$ unit vector directed upward

$f:$ Coriolis parameter

$\beta: d f / d y$

$K_{t}$ : vertical mixing coefficient of temperature for convective adjustment

$\Gamma:$ critical lapse rate in convective adjustment

$K_{m}$ : vertical momentum mixing coefficient

$c_{D}$ : drag coefficient of momentum at the surface

$k$ : relaxation time constant for Newtonian Cooling

$T_{e}:$ equilibrium temperature

$h:$ topographic height

$\zeta$ : vorticity

$K:$ kinetic energy

$A:$ available potential energy

(-) : 16-day time mean

()$^{\prime}$ : departure from 16-day time mean

\section{Appendix II: $T_{e}$ and $U_{e}$ in equilibrium state}

Original geostrophic wind data by Crutcher (1961) and Berlin maps are given at every $5^{\circ}$ latitude grid point from the equator to the north 
pole at surface, $850,700,500,300,200,100$, 50,30 and $10 \mathrm{mb}$. Surface pressure and temperature are also needed to calcuate the variables at the surface. $\Phi$ is obtained by integrating the geostrophic relation as:

$$
\Phi(\phi)=\Phi\left(45^{\circ} \mathrm{N}\right)-\int_{45^{\circ}}^{\phi} a\left(f+\frac{u}{a} \tan \phi\right) u d \phi .
$$

Temperature is computed from the hydrostatic relationship:

$$
T=-\frac{1}{R} \frac{\partial \Phi}{\partial \ln p} .
$$

The computed temperature is defined at the middle of the pressure levels of the observation where wind data are defined. We then interpolated the temperature at $10 \sigma$-levels in the model, assuming surface pressures in the model are equal to those of observation. Splines under tension (NCAR, 1976) is used for interpolation.

In order to eliminate small scale irregularity which may appear in the interpolation process, we expanded variables with respect to latitudes following Kasahara (1980) as:

$$
\begin{aligned}
& u=\sum_{m=1}^{18} u_{m} \cos (2 m-1) \phi, \\
& \Phi=\sum_{m=0}^{18} \Phi_{m} \cos 2 m \phi, \\
& T=\sum_{m=0}^{18} T_{m} \cos 2 m \phi,
\end{aligned}
$$

Here, we set cosine coefficients $\left(u_{m}, \Phi_{m}\right.$ and $\left.T_{m}\right)$ for $m$ greater than 9 to zero and synthesized them at latitudinal grid points. Initial zonal wind $u$ is calculated from $T_{e}$ using hydrostatic and geostrophic equations which are similar to those in the numerical model. Meridional velocity $v$ is zero.

\section{Appendix III: Interpolation from $\sigma$ to $p$}

Predicted variables are $u, v, T$ and $p_{s}$ in the model. $u$ and $v$ are then interpolated to $T$-grid points where $T$ and $\Phi$ are defined in a staggered grid of the model. $\Phi$ is calculated by the model's hydrostatic equation. $\omega$ is obtained by:

$$
\omega=\pi \dot{\sigma}-\sigma\left(\pi \nabla_{\sigma} \cdot v+\frac{\partial \pi \dot{\sigma}}{\partial \sigma}\right),
$$

where $\nabla_{\theta} \cdot v$ represents divergence on a constant $\sigma$-surface. Divergence and vorticity on a constant pressure surface, i.e., $\nabla_{p} \cdot v$ and $\zeta_{p}$ are obtained from the corresponding values on constant $\sigma$-surface as

$$
\begin{aligned}
& \nabla_{p} \cdot \boldsymbol{v}=\nabla_{\sigma} \cdot \boldsymbol{v}-\frac{\partial \ln p_{s}}{\partial x} \frac{\partial u}{\partial \ln \sigma}-\frac{\partial \ln p_{s}}{\partial y} \frac{\partial v}{\partial \ln \sigma} . \\
& \zeta_{p}=\frac{\partial v}{\partial x}-\frac{\partial u \cos \phi}{\cos \phi \partial y}-\frac{\partial \ln p_{s}}{\partial x} \frac{\partial v}{\partial \ln \sigma} \\
& +\frac{\partial \ln p_{s}}{\partial y} \frac{\partial u}{\partial \ln \sigma} .
\end{aligned}
$$

where the horizontal differential is on a constant $\sigma$-surface. All variables at $\sigma$ levels are interpolated to reference pressure levels from $950 \mathrm{mb}$ to $50 \mathrm{mb}$ with $50 \mathrm{mb}$ intervals by the splines under tension (NCAR, 1976).

\section{Appendix IV: Transient eddy energy equation}

Primitive equations in pressure coordinates may be written as:

$$
\begin{aligned}
& \frac{\partial u}{\partial t}=-u \frac{\partial u}{\partial x}-v \frac{\partial u}{\partial y}-\omega \frac{\partial u}{\partial p}+\left(f+\frac{\tan \phi}{a} u\right) v \\
&-\frac{\partial \Phi}{\partial x}+F_{x}, \quad(\mathrm{~A} 7) \\
& \frac{\partial v}{\partial t}=-u \frac{\partial v}{\partial x}-v \frac{\partial v}{\partial y}-\omega \frac{\partial v}{\partial p}-\left(f+\frac{\tan \phi}{a} u\right) u \\
&-\frac{\partial \Phi}{\partial y}+F_{y}, \text { (A 8) } \\
& \frac{\partial T}{\partial t}=-u \frac{\partial T}{\partial x}-v \frac{\partial T}{\partial y}-\omega \frac{\partial T}{\partial p}+\frac{\kappa}{p} \omega T+Q, \\
& \frac{\partial u}{\partial x}+\frac{\partial v}{\partial y}+\frac{\partial \omega}{\partial p}=0, \\
& \frac{\partial \Phi}{\partial p}=-\frac{R T}{p} .
\end{aligned}
$$

Subtracting the corresponding time mean equations from (A7), (A8), and (A9), respectively, we obtain equations for deviations from time means; for example, for $u^{\prime}$ :

$$
\begin{aligned}
\frac{\partial u^{\prime}}{\partial t}= & -\left\{\bar{u} \frac{\partial u^{\prime}}{\partial x}+\bar{v} \frac{\partial u^{\prime}}{\partial y}+\bar{\omega} \frac{\partial u^{\prime}}{\partial p}-\left(f+\frac{\tan \phi}{a} \bar{u}\right) v^{\prime}\right\} \\
& -\left\{u^{\prime} \frac{\partial \bar{u}}{\partial x}+v^{\prime} \frac{\partial \bar{u}}{\partial y}+\omega^{\prime} \frac{\partial \bar{u}}{\partial p}-\frac{\tan \phi}{a} u^{\prime} \bar{v}\right\} \\
& -\left\{u^{\prime} \frac{\partial u^{\prime}}{\partial x}+v^{\prime} \frac{\partial u^{\prime}}{\partial y}+\omega^{\prime} \frac{\partial u^{\prime}}{\partial p}-\frac{\tan \phi}{a} u^{\prime} v^{\prime}\right. \\
& \left.-\left(\overline{u^{\prime} \frac{\partial u^{\prime}}{\partial x}}+\frac{\partial v^{\prime} \frac{\partial u^{\prime}}{\partial y}}{\partial \omega^{\prime} \frac{\partial u^{\prime}}{\partial p}}-\frac{\tan \phi}{a} \overline{u^{\prime} v^{\prime}}\right)\right\} \\
& -\frac{\partial \Phi^{\prime}}{\partial x}+F_{x} .
\end{aligned}
$$

Multiplying the $u^{\prime}$-equation by $u^{\prime}$ and the $v^{\prime}$ equation by $v^{\prime}$ and adding them together, we 
can obtain the transient eddy kinetic energy equation. Thus, the time averaged eddy kinetic energy equation may be written as:

$$
\frac{\partial \overline{K^{\prime}}}{\partial t}=L K+N K+I\left(\bar{K}, K^{\prime}\right)+P K+F K,
$$

where

$$
\begin{aligned}
& L K=-\left(\bar{u} \frac{\partial \overline{K^{\prime}}}{\partial x}+\bar{v} \frac{\partial \overline{K^{\prime}}}{\partial y}+\bar{\omega} \frac{\partial \overline{K^{\prime}}}{\partial p}\right), \\
& N K=-\left(\overline{u^{\prime} \frac{\partial K^{\prime}}{\partial x}}+\overline{v^{\prime} \frac{\partial \bar{K}^{\prime}}{\partial y}}+\overline{\omega^{\prime} \frac{\partial K^{\prime}}{\partial p}}\right), \\
& I\left(\bar{K}, K^{\prime}\right)=-\left(\overline{u^{\prime} u^{\prime}} \frac{\partial \bar{u}}{\partial x}+\overline{u^{\prime} v^{\prime}} \frac{\partial \bar{u}}{\partial y}+\overline{u^{\prime} \omega^{\prime}} \frac{\partial \bar{u}}{\partial p}\right. \\
& -\frac{\tan \phi}{a} \overline{u^{\prime} u^{\prime}} \bar{v}+\overline{u^{\prime} v^{\prime}} \frac{\partial \bar{v}}{\partial x}+\overline{v^{\prime} v^{\prime}} \frac{\partial \bar{v}}{\partial y} \\
& \left.+\overline{v^{\prime} \omega^{\prime}} \frac{\partial \bar{v}}{\partial p}+\frac{\tan \phi}{a} \overline{u^{\prime} v^{\prime}} \bar{u}\right), \\
& P K=-\left(\overline{u^{\prime} \frac{\partial \Phi^{\prime}}{\partial x}}+\overline{v^{\prime} \frac{\partial \Phi^{\prime}}{\partial y}}\right)=-\overline{v^{\prime} \cdot \nabla \Phi^{\prime}}, \\
& F K=\overline{u^{\prime} F_{x^{\prime}}}+\overline{v^{\prime} F_{y^{\prime}}} \text {. }
\end{aligned}
$$

$L K$ and $N K$ denote advections of transient eddy kinetic energy by time mean winds and transient eddy flows, respectively. $I\left(\bar{K}, K^{\prime}\right)$ denotes the barotropic interaction between time mean winds and transient disturbances. $P K$ represents the pressure work and $F K$ is the frictional dissipation of transient eddy kinetic energy.

Using (A10) and (A11), the pressure work term $P K$ may be divided into the following terms:

$$
P K=F G 1+F G 2+I\left(A^{\prime}, K^{\prime}\right),
$$

where

$$
\begin{aligned}
& F G 1=-\frac{\partial}{\partial x} \overline{u^{\prime} \Phi^{\prime}}-\frac{\partial}{\partial y} \overline{v^{\prime} \Phi^{\prime}}=-\nabla \cdot \overline{v^{\prime} \Phi^{\prime}}, \\
& F G 2=-\frac{\partial}{\partial p} \overline{\omega^{\prime} \Phi^{\prime}} \\
& I\left(A^{\prime}, K^{\prime}\right)=-\frac{R}{p} \overline{\omega^{\prime} T^{\prime}} .
\end{aligned}
$$

FG1 (FG2) denotes horizontal (vertical) convergence of eddy geopotential energy flux. $I\left(A^{\prime}, K^{\prime}\right)$ is the baroclinic conversion between transient eddy available potential energy and kinetic energy.

Referring to Lorenz (1955), the transient eddy available potential energy equation may be obtained by multiplying $T^{\prime}$-equation by $T^{\prime} / \gamma$ where

$$
\gamma=\frac{R}{p}\left(\frac{\partial \bar{T}}{\partial p}-\frac{\kappa}{p} \bar{T}\right) .
$$

An approximate from of the time averaged eddy available potential energy equation may be written as:

$$
\frac{\partial \overline{A^{\prime}}}{\partial t}=L A+N A+I\left(\bar{A}, A^{\prime}\right)+Q A+E A,
$$

where $T^{\prime}=T^{\prime 2} /(2 \gamma)$, and

$$
\begin{aligned}
& L A=-\left(\bar{u} \frac{\partial \overline{A^{\prime}}}{\partial x}+\bar{v} \frac{\partial \overline{A^{\prime}}}{\partial y}+\bar{\omega} \frac{\partial \overline{A^{\prime}}}{\partial p}\right), \\
& N A=-\left(\overline{u^{\prime} \frac{\partial A^{\prime}}{\partial x}}+v^{\prime} \frac{\partial A^{\prime}}{\partial y}+\overline{\omega^{\prime}} \frac{\partial A^{\prime}}{\partial p}\right), \\
& I\left(\bar{A}, A^{\prime}\right)=-\frac{1}{\gamma}\left(\overline{u^{\prime} T^{\prime}} \frac{\partial \bar{T}}{\partial y}+\overline{v^{\prime} T^{\prime}} \frac{\partial \bar{T}}{\partial y}\right) \\
& \quad+\frac{R}{p} \overline{\omega^{\prime} T^{\prime}}, \\
& Q A=\frac{1}{\gamma} \overline{Q^{\prime} T^{\prime}}, \\
& E A=-\left(\bar{u} \frac{\partial \ln \gamma}{\partial x}+\bar{v} \frac{\partial \ln \gamma}{\partial x}+\bar{\omega} \frac{\partial \ln \gamma}{\partial p}\right. \\
&\left.\quad+\frac{2 \kappa}{p} \overline{\bar{\omega}}\right) \overline{A^{\prime}}+\left(\overline{u^{\prime} A^{\prime}} \frac{\partial \ln \gamma}{\partial x}+\overline{v^{\prime} A^{\prime}} \frac{\partial \ln \gamma}{\partial y}\right. \\
&\left.\quad+\overline{\omega^{\prime} A^{\prime}} \frac{\partial \ln \gamma}{\partial p}-\frac{2 \kappa}{p} \overline{\omega^{\prime} A^{\prime}}\right) .
\end{aligned}
$$

$L A$ and $N A$ denote advection of transient eddy available potential energy by time mean winds and transient eddy flow, respectively. $I\left(\bar{A}, A^{\prime}\right)$ term is the conversion from time mean available potential energy to transient eddy available potential energy. The term $(R / p) \overline{\omega^{\prime} T^{\prime}}$ in $\left(I \bar{A}, A^{\prime}\right)$ corresponds to baroclinic conversion term $-I\left(A^{\prime}, K^{\prime}\right) . Q A$ is the generation of eddy available potential energy due to diabatic heating. The first term in $E A$ is related to variations in the mean static stability $\gamma$ with respect to $x, y$, and $p$, while the second term represents triple correlation effects. The $E A$ term is generally small and can be omitted (refer to Lorenz, 1955).

\section{References}

Arakawa, A., 1972: Design of the UCLA general circulation model. Tech. Rept. No. 7, Dept. of Meteorology, University of California, $116 \mathrm{pp}$.

- and M. J. Suarez, 1983: Vertical differencing of the primitive equations in sigma-coordinates. Mon. Wea. Rev., 111, 34-45.

Bleck, R., 1977: Numerical simulation of lee cyclogenesis in the Gulf of Genoa. Mon. Wea. Rev., $105,428-445$.

Buzzi, A., and S. Tibaldi, 1977a: Inertial and frictional effects on rotating stratified flow over topo- 
graphy. Quart. J. Roy. Met. Soc., 103, 135-150. $\longrightarrow$, and $\longrightarrow, 1977 \mathrm{~b}$ : Cyclogenesis in the lee of the Alps: A case study. Quart. J. Roy. Met. Soc., 104, 271-287.

Carlson, T. N., 1961: Lee-side front genesis in the Rocky Mountains. Mon. Wea. Rev., 89, 163172.

Chang, C.-P., J. E. Erickson, and K. M. Lau, 1979: Northeasterly cold surges and near-equatorial disturbances over the Winter MONEX area during December 1974. Part I: Synoptic aspects. Mon. Wea. Rev., 107, 812-829.

Chung, Y.-S., K. D. Hage, and E. R. Reinelt, 1976: On lee cyclogenesis and airflow in the Canadian Rocky mountains and the East Asian mountains. Mon. Wea. Rev., 104, 879-891.

Corby, G. A., A. Gilchrist, and R. L. Newson, 1972: $A$ general circulation model of the atmosphere suitable for long period integrations. Quart. J. Roy. Met. Soc., 98, 809-832.

Crutcher, H. L., 1961: Meridional cross-sections of upper winds over the Northern Hemisphere. Tech. Pap. No. 41, U.S. Weather Bureau, Department of Commerce, Washington, D.C., 307 pp.

Egger, J., 1972: Numerical experiments on the cyclogenesis in the Gulf of Genoa. Beitr. Phys. Atmos., 45, 320-346.

Fultz, D., and R. R. Long, 1951: Two-dimensional flow around a circular barrier in a rotating spherical shell. Tellus, 3, 61-68.

Huppert, H. E., and K. Bryan, 1976: Topographically generated eddies. Deep-Sea Res., 23, 655679.

Kasahara, A., 1979: Influence of orography on the atmospheric general circulation. GARP Publication Series, No. 20, World Meteorological Organization.

- 1980: Effect of zonal flows on the free oscillations of a barotropic atmosphere. J. Atmos. Sci., 37, 917-928.

Kirwood, E., and J. Derome, 1977: Some effects of the upper boundary condition and vertical resolution on modeling forced stationary planetary waves. Mon. Wea. Rev., 105, 1239-1251.

Lorenz, E. N., 1955: Available potential energy and the maintenance of the general circulation. Tellus, 7, 157-167.

Manabe, S., and T. B. Terpstra, 1974: The effects of mountains on the general circulation of hte atmosphere as identified by numerical experiments. J. Atmos. Sci., 31, 3-42.

Murakami, T., 1981a: Orographic influence of the Tibetan Plateau on the Asiatic winter monsoon circulation. Part I. Large-scale aspects. J. Meteor. Soc. Japan, 59, 40-65.

- 1981b: Orographic influence of the Tibetan Plateau on the Asiatic winter monsoon circu- lation. Part III. Short-period oscillations. J. Meteor. Soc. Japan, 59, 173-200.

, 1981c: Orographic influence of the Tibetan Plateau on the Asiatic winter monsoon circulation. Part IV. Long-period oscillations. J. Meteor. Soc. Japan, 59, 201-219.

Nakamura, H., 1976: Some problems in reproducing planetary waves by numerical models of the atmosphere. J. Meteor. Soc. Japan, 54, 129-146.

- 1978a: Dynamical effects of mountains on the general circulation of the atmosphere: I. Development of finite-difference schemes suitable for incorporating mountains. J. Meteor. Soc. Japan, 56, 317-340.

$\longrightarrow, 1978 \mathrm{~b}$ : Dynamical effects of mountains on the general circulation of the atmosphere: II. Effects of mountain barriers on the barotropic jet. J. Meteor. Soc. Japan, 56, 341-352.

NCAR, 1976: NCAR Software Support Library, Vol. 1. NCAR Technical Notes (NCAR/TN-105 +IA), Revision I.

Phillips, N. A., 1957: A coordinate system having some special advantages for numerical forecasting. J. Meteor., 14, 184-185.

- - 1974: Application of Arakawa's energy conserving layer model to operational numerical weather prediction. Office Note 104, U.S. Dept. of Commerce, NOAA, NWS, NMC, $40 \mathrm{pp}$.

Research group on the simulation of the general circulation, the Institute of Atmospheric Physics, Academia Sinica, 1977: An annulus experimental simulation of the low vortex to the SE of Chinghai-Tibetan Plateau. Scientia Sinica, 20, 64-74.

Simmons, A. J., and D. M. Burridge, 1981: An energy and angular momentum conserving vertical finite-difference scheme and hybrid vertical coordinates. Mon. Wea. Rev., 109, 758-766.

Speranza, A., 1975: The formation of baric depressions near the Alps. Annali di Geofisica, 28, 177-217.

Staff Members, Academia Sinica, 1957: On the general circulation over Eastern Asia (I). Tellus, 9, 432-446.

- 1958a: On the general circulation over Eastern Asia (II). Tellus, 10, 58-75.

- 1958b: On the general circulation over Eastern Asia (III). Tellus, 10, 299-312.

Taylor, G. I., 1923: Experiments on the motion of solid bodies in rotating fluids. Proc. Roy Soc. London, A104, 213-218.

Trevisan, A., 1975: Numerical experiments on the influence of orography on cyclone formation with an isentropic primitive equation model. J. $A t$ mos. Sci., 33, 768-780.

Yeh, T.-C., and C.-C. Chang, 1974: A preliminary experimental simulation on the heating effect of the Tibetan Plateau on the general circulation 
over eastern Asia in summer. Scientia Sinica, 17, $397-420$. the Tibetan Plateau (in Chinese). Beijing Scientific Press, $278 \mathrm{pp}$.

\title{
数值実験から見たコールド・サージとリー・サイクロジェネシスに 及ぼす山岳の影翠
}

\section{第 1 部 時间平均場}

\author{
中 村 \\ 東京大学理学部地球物理学教室

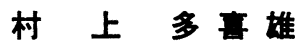 \\ ハワイ大学気象教室
}

対流調節, 地面摩擦, 運動量の鈶直渦混合を含んだ10層の数值モデルを用いて，冬季移動性俆乱に及ぼす山岳 の力学効果を調べた。熱的効果はニュートン冷却の形に簡単化し, その平衡状態として冬の帯状平均の温度場を 与えた。山の形は簡単な楕円形である。時間積分は72日まで行なったが，21日から36日までの16日間についてだ け詳しい解析を行なった。

16日平均場から，下部対流圈では偏西風ジェットは山を乗り越えるのではなくむしろ迂回して流れ2つに分流 することが示された。 $500 \mathrm{mb}$ ではジェットは山の上で最も弱く，山の南北にはっきりと分離して流れる。300 $\mathrm{mb}$ 以上ではジェットは山の南側を流れている。これらの事実は, 1978-79 の冬の定常場と良く一致する (Murakami, 1981a)。

$850 \mathrm{mb}$ では，湿著な温度嗳乱が山の北西端に発生し，時計回りに山の周りを払がり山の南側にまで到達する。 この摄乱は $700 \mathrm{mb}$ 以下の下層に限られている。按乱はその渦有効位置エネルギーを，16日平均の温度場との 非線形相互作用によって得ている。しかし渦有効位置エネルギーは渦運動エネルギーに変換されない。つまり， 傾圧的エネルギー变换過程はこの掫乱の発達にほとんど寄与しない。その渦運動ェネルギーは, 非地衡風成分の 風による渦ジオ・ポテンシャル・エネルギーのフラックスの収束から得ている。

$500 \mathrm{mb}$ では, 山の上では摄乱の運動エネルギーは最も弱く, 傾圧的エネルギー变換は消運動エネルギーから 有効位置エネルギーに向っている。按乱の運動エネルギーを作り出す主な過程は, 渦ジオ・ポテンシャル・ェネ ルギーの水平フラックスの収束である。掫乱は16日平均の風に, 山の外（内）側でェネルギーを供給して（受取 って) いる。

$200 \mathrm{mb}$ では, 強いジェット・ストリームが流れている山の南に大きな渦運動ェネルギーの帯が横たわってい る。順圧過程は16日平均の偏西風にエネルギーを供給している。ここでもまた，渦運動エネルギーは主にジオ・ ポテンシャル・エネルギーの水平収束によって作られており，傾圧変換など他の項は無視できる。 